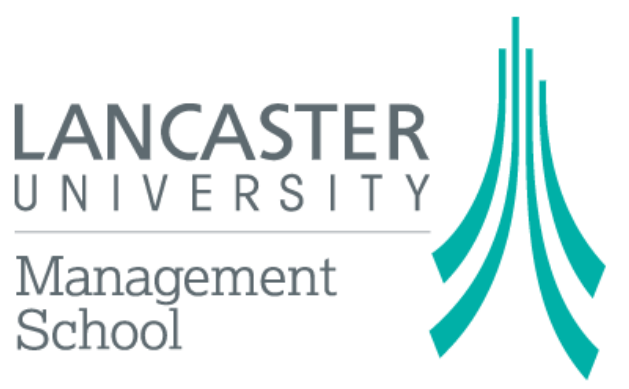

Economics Working Paper Series

2014/008

\title{
The Effect of Personality Traits on Subject Choice and Performance in High School: Evidence from an English Cohort
}

Silvia Mendolia and Ian Walker

The Department of Economics

Lancaster University Management School

Lancaster LA1 4YX

UK

(C) Authors

All rights reserved. Short sections of text, not to exceed two paragraphs, may be quoted without explicit permission, provided that full acknowledgement is given. 


\title{
The Effect of Personality Traits on Subject Choice and Performance in High School: Evidence from an English Cohort
}

\author{
Silvia Mendolia ${ }^{\dagger}$, and lan Walker ${ }^{\ddagger}$ \\ ${ }^{\dagger}$ University of Wollongong, \\ School of Accounting, Economics and Finance_silvia_mendolia@uow.edu.au \\ ${ }^{\ddagger}$ Lancaster University, Department of Economics ian.walker@lancaster.ac.uk
}

Keywords: Personality, Education, Locus of Control, Self-Esteem

JEL codes: I10, 121

\begin{abstract}
:
This paper investigates the relationship between personality traits in adolescence and performance in high school using a large and recent cohort study. In particular, we investigate the impact of locus of control, self-esteem, and work ethics at age 15, on test scores at age 16, and on subject choices and subsequent performance at age 17-18. In particular, individuals with external locus of control or with low levels of self-esteem seem less likely to have good performance in test scores at age 16 and to pursue further studies at 17-18, especially in mathematics or science.

We use matching methods to control for a rich set of adolescent and family characteristics and we find that personality traits do affect study choices and performance in test scores - particularly in mathematics and science. We explore the robustness of our results using the methodology proposed by Altonji et al. (2005) that consists in making hypotheses about the correlation between the unobservables that determine test scores and subjects' choices and the unobservables that influence personality.
\end{abstract}

Corresponding author: Dr. Silvia Mendolia, School of Accounting, Economics, and Finance, Faculty of Business, Building 40, Room 215, University of Wollongong, NSW 2522, Australia 


\section{Introduction}

The objective of this paper is to analyse the role of non-cognitive traits on performance in High School. In particular, we study the effect of locus of control, self-esteem and work ethics recorded when the child is 15-16 on: subsequent test scores in English and Mathematics at age 16; on the likelihood of choosing different subjects beyond 16; and subsequent performance at age 18 in those subjects.

We contribute to the existing literature in several ways. First, we provide evidence from a recent dataset based on a large cohort of English children born in 1990 and followed for seven years, starting in 2004. Our analysis is focused on personality traits in adolescence. A variety of studies have shown that the Big Five personality traits are relatively malleable, at least over the early life cycle and then tend to be stable during adult life (Cobb-Clark and Schurer, 2012 and 2013). There is some evidence that policy interventions can promote useful traits and suppress harmful ones early in life and, while cognitive skills (such as IQ, for example) are believed to be relatively stable by the age of 8 , other aspects of personality might be easier to change at a later age (see Carneiro and Heckman, 2003 for a discussion). Existing studies mostly rely on relatively dated data (for example NLSY1979 for Heckman et al., 2006 and Cebi, 2007; NELS1988 for Coleman and Deleire, 2003; UK NCDS1958 for Carneiro et al., 2007), or do not have a specific focus on adolescents (Chamorro et al., 2003; Delaney et al., 2013). Secondly, we have a great deal of information on test scores by subject at different ages, including students' choices of subjects which are very important for entry into higher education. We use this information to investigate the role of different personality traits on choice of study and performance. The existing literature is mostly focused on the broad effect of personality on education, using indicators such as years of schooling, or college graduation (Heckman et al. 2006; Coleman and Deleire, 2003; Cebi, 2007) and focusing on the role of one specific personality trait, such as locus of control or 
conscientiousness (Baron and Cobb-Clark, 2010). Thirdly we use propensity score matching (PSM) to investigate the relationship between personality and High School performance as well as OLS estimation, and we examine the robustness of our results using the methodology proposed by Altonji et al. (2005) (the AET method). This method does not rely on any identifying exclusion restrictions but instead, uses observed differences between those with and without a particular personality trait to provide information regarding the likely magnitude and direction of selection along unobserved characteristics. OLS is widely regarded as providing an estimate of an upper bound on the causal effect. PSM, by focussing on treatments and controls that are observably comparable, is thought to provide closer estimates to the causal effect than OLS because it seems plausible that observations for which there is common support will also be more similar in their unobservable determinant of the outcome. AET may be regarded as a method that could tighten the PSM bound by exploring how the estimated causal effects varies as the correlation between unobservables and the outcome relative to the correlation between observables and the outcome. The AET estimate will be identical to OLS if there is no correlation between the treatment and the unobservables. An interesting case is the AET estimate provided when it is assumed that the correlation between the treatment and the unobservable is the same as that between the treatment and the observables. This special case corresponds to what we might expect to estimate if the available observable variables were a random selection of all relevant variables. A well designed survey that is closely matched to the needs of the research question would presumably do better than this. Thus, this special case might be regarded a worst case and so provides a lower bound. Intermediate cases correspond to the informal methodology of estimating models with sequentially more explanatory variables to establish the stability of the estimated causal effect. 
Fourthly, we analyse the different impact of personality traits on children across various markers of deprivation. In particular, we look at disadvantaged families, where disadvantage is defined in a variety of ways, and we analyse the effect of different noncognitive skills for them, compared to their advantaged peers. We examine whether personality traits can play a different role for children who are less likely to receive support in their education from their families. The results broadly support the idea that the effect of personality traits is particularly strong for the cognitive outcomes for children who come from disadvantaged socio-economic backgrounds while the effect on advantaged children is limited. These results would support the use of policies that improve academic achievement for students from disadvantaged socio-economic background through encouraging positive personality traits.

Finally, we focus on understanding the role of personality traits on performance in different subjects at age 16 and on subsequent subject choices and performance at age 18 . In particular, we try to understand whether some specific traits are more beneficial (or detrimental) for performance in some particulars subjects. In particular, some research suggests that maths skills play an important role in determining earnings, even controlling for educational attainment in general (see Joensen and Skyt Nielsen, 2009, for example). Here we distinguish between English and Mathematics at age 16 and between English, Mathematics, and Science at age 18. While the determinants of performance in a particular subject (rather than the overall school performance) are very hard to disentangle, it is possible that personality traits play a role in enhancing performance in one area, rather than another. The issue seems to be particularly relevant for the British population: the UK ranking of 15years old pupils in Mathematics and Science in the OECD's PISA tests has been falling from 2000 to 2009 and was just below the OECD average in Mathematics and only slightly above in Science. A key contributing factor to UK’s STEM (Science, Technology, Engineering and 
Mathematics) deficit is the very low General Certificate of Secondary Education (GCSE) performance at 16 in Science and Mathematics subjects. High level passes in these subjects at this level is a pre-requisite for further study in these same subjects. Not surprisingly, the UK has one of the lowest shares of 15-year olds intending a STEM career among the OECD countries and still lags behind most OECD countries in women's aspirations to study a STEM subject and engage in a STEM career (see OECD, 2012).

The rest of this paper is organized as follows. Section 2 provides a brief overview of the existing literature; Section 3 presents the data and explains the personality indicators and outcomes that it contains; Section 4 and 5 discuss the estimation methods and the results; and Section 6 concludes with a discussion of the policy implications of the work. The headline finding of the research is that we broadly support the idea that non-cognitive skills are important in determining performance in high school, particularly in Mathematics and Science. Individuals with external locus of control, low self-esteem, and low levels of work ethics ${ }^{1}$ are all less likely to achieve good results at the end of High School and less likely to specialize in mathematical or scientific subjects for their final exams before applying to university.

\section{Overview of the existing literature}

The evidence on the effect of personality on educational outcomes has suggested a variety of transmission mechanisms, such as study behaviours, effort, and attention skills. Almlund et al. (2011) provides an excellent review of the studies conducted in this area.

Research in personality psychology has produced the widely shared taxonomy of traits, known as the Big Five. The Big Five are five factors (Openness to Experience, Conscientiousness, Extraversion, Agreeableness, and Neuroticism or Emotional Stability)

\footnotetext{
${ }^{1}$ These concepts are explained and defined in Section 3.
} 
that represent personality traits at the broadest level of abstraction. They summarize a large number of distinct, more specific, personality facets (Almlund et al., 2011). Almlund et al. (2011) conclude that personality traits have a strong effect on educational attainment, grades and test scores. In particular, they show that Openess to Experience and Conscientiousness are very important in determining years of education, grades and test scores; and that Conscientiousness might be as predictive as cognitive ability in determining good school results, with the effect being mediated through effort and positive study habits. On the other hand, locus of control and self-esteem are found to have important effects on adolescent schooling decisions.

Extensive research in psychology and sociology has shown that internal locus of control and high conscientiousness are associated with better academic performance, increased years of schooling and greater chances to go to university (see for example Goldberg et al., 1998, and Wang et al., 1999 for reviews). However, most of these studies tend to use small or unrepresentative samples and focus on correlation between personality and educational outcomes rather than on understanding the causal relationship. Duckworth and Seligam, 2005, Ross and Broh, 2000, and Poropat, 2009 provide meta-analyses that aim to overcome the former shortcoming, but not the latter.

The number of studies in economics that analyse the importance of non-cognitive skills on educational outcomes has grown substantially in recent years. However, the economics literature in this area is mostly based on relatively dated data and sometimes provides conflicting findings. Furthermore, most of the existing studies focus on what happens at the end on individuals' education (college performance), or analyses broad indicators of educational achievements (years of schooling), rather than performance at a younger age and in specific subjects. Table 1 provides a summary of the most relevant and recent economics studies on personality and education. 


\section{Table 1 here}

One of the most notable examples of the relevance of non-cognitive skills is provided by Heckman and Rubinstein (2001) who analyse the performance of Graduate Equivalence Diplomas (GED) recipients and conclude that their lower achievements in the labour market and the higher prevalence of criminal or risky behaviours can be attributed to the lack of noncognitive skills such as discipline, patience or motivation. Other work by Heckman and collaborators has emphasized the importance of investing in promoting positive noncognitive skills from a very early age (see for example studies on the Perry Preschool program, such as Heckman and Masterov, 2007 and Heckman et al., 2010). Heckman, et al. (2006) use data from the US NLSY1979 and show that locus of control and self-esteem affect years of schooling and college performance.

Coleman and Deleire (2003) use NELS1988 to incorporate locus of control into a human capital investment model and show that teenagers with internal locus of control are more likely to make educational investments, such as complete high school and attend a fouryear college. On the other hand, Cebi (2007) replicates the Coleman and Deleire (2003) study using NLSY and suggest that locus of control is not a significant determinant of educational outcomes, even if it is rewarded in the labour market.

Lundberg (2013) analyses the impact of cognitive ability and personality traits on college graduation in a recent cohort of young Americans, and how the returns to these traits vary by family background. Her work finds relevant differences across family background groups, particularly for men. Conscientiousness does not seem to have an effect on the education of disadvantaged men, while openness to experience has a relevant effect on college graduation only for less-advantaged men and women. 
In the European context, several studies have suggested positive returns to noncognitive traits, and point to the role of social skills (Carneiro et al., 2007, Silles, 2010, Duckworth and Seligman, 2005, and Duckworth and Schoon, 2010) or the impact of positive study behaviours (Delaney et al., 2013). Duncan et al. (2007) focuses on school readiness, comparing data from UK, US and Canada and show that attention skills are good predictors of educational achievements while other measures of socio-emotional behaviours seem less important. Borghans et al. (2008) show that, in an experimental setting, people with internal locus of control respond less to financial incentives when allocating effort to cognitive tasks, probably because they are more highly motivated. Finally, Baron and Cobb-Clark (2010) analyse the link between locus of control and high school graduation and university attendance using a recent cohort of Australian youths. Their work shows that people with internal locus of control are more likely to invest in their education and they do not find any significant relationship between family welfare history and young person's locus of control.

Our own analysis is particularly important because of the recent attention in the literature to quantify returns to literacy and numeracy skills, and returns to human capital investments in the STEM subjects. For example, Crawford and Cribb (2013) use the 1970 BCS to study the relationship between reading and mathematics skills measured at age 10 and weekly earnings and hourly wages at ages 30, 34 and 38. They control for a rich set of demographic and family background characteristics and they find that a one standard deviation increase in age 10 mathematics (reading) scores is associated with 10\% (5\%) higher earnings during one's 30s. Dolton and Vignoles (2002) also show a very large effect of having Mathematics A-Level (typically at age 18) on subsequent earnings, even after controlling for higher education.

In the US, a few studies have taken advantage of curriculum reforms. For example, Cortes et al (2013) find that an extra high school Mathematics course had large effects on test 
scores, high school graduation and participation in higher education. Finally, one of the most relevant studies in this area is Joensen and Nielsen (2009) who estimate the causal effect of studying advanced high school mathematics by exploiting an educational reform that changed the possible combinations of subjects with mathematics in Denmark. They show that taking an advanced mathematics course in combination with an advanced chemistry course increases earnings by $20 \%$ relative to chemistry without mathematics.

\section{Data}

This paper uses data from the Longitudinal Study of Young People in England (LSYPE). This is a large-scale cohort survey of English adolescents, selected to be representative of the young people in England but at the same time as oversampling specific groups. Adolescents were interviewed for the first time when they were in school year 9 in 2004 at the age of 14. LSYPE can be linked to the National Pupil Database (NPD), a pupillevel administrative database that matches pupil and school characteristics data to pupil attainment and contains detailed information on test scores for all the LSYPE children. We use this data to obtain information about LSYPE children's results in test scores in Year 11 at age 16-17 (GCSE scores) and age 17-18 (A levels scores).

In the first wave around 15,500 young people were interviewed. In the first four waves, parents/guardians were also interviewed. Our final sample includes around 5,500 observations of children with non-missing information on personality traits, test scores, and other essential information on the child's birth and family background (the selected observations were not significantly different from the original data in terms of their observable characteristics). The study is managed by the Department of Education and covers a wide range of topics, including academic achievements, family relationships, attitudes toward school, family and labour market, and some more sensitive or challenging issues, such 
as risky health behaviours (smoking, alcohol drinking, drug taking), personal relationships, etc.

\subsection{Outcomes}

We are interested in testing the effect of personality traits on a variety of cognitive outcomes (test scores) at various ages and in different subjects, and on the chances that a child will take further studies after compulsory education. Table 2 lists the outcomes we use in our analysis and the age of the child for each outcome. We focus on the following outcomes:

- GCSE at age 16: At the end of Key Stage 4 (from 13 to 16 years old), pupils generally take the national public GCSEs in most subjects studied - often in as many as 10 subjects. GCSE grades range from $A *$ to G. Our dependent variables include: the number of subjects with "pass" grades from $A^{*}$ to $C$ in GCSE exams; a binary variable indicating having 5 GCSE passes including Mathematics and English which is usually required for students following an academic track for progression beyond age 16; and two binary variables equal to 1 if the child attained $A^{*}$ to $C$ in English and Mathematics.

- Decision to take General Certificate of Education Advanced (A levels): A level subjects are studied over a two-year period. A-levels are administered by an official assessment body. Most students study three or four subjects simultaneously during Year 12 and Year 13 (ages 17-18), either in their secondary education school or in post-16 colleges. A-levels are taken at age 18 and are the main admission criterion for university admission. Elite institutions or high demand courses usually require high 
grades, while admission to less prestigious institutions and less popular subjects will may be possible with lower grades. ${ }^{2}$

- A level subjects studied: students usually select three to four subjects for their A levels, depending on their academic preferences and intentions toward further education. Some universities and/or some degrees will have specific requirements in terms of A-level subject studied and grades. The most commonly demanded subjects in university entry requirements, known as 'facilitating' subjects, are: Biology, Chemistry, Physics ${ }^{3}$, English, Geography, History, Mathematics, Modern and Classical Languages.

- $\quad$ Grades in A levels by subject: The passing grades for A-levels are A*, A, B, C, D and E. Grades are often translated into points for aggregation purposes as follows: 120 points for A, 100 for B, 80 for C, 60 for D, and 40 for $\mathrm{E}$.

Table 2 here

\subsection{Personality traits}

Personality is complex and factor analysis has been utilised extensively in personality psychology to identify a number of common factors derived from a variety of questions (Cobb-Clark et al., 2014; Piatek and Pinger 2010; and Almlund et al., 2011). While our data does not include information about the "Big Five" personality traits that have been the focus of some recent research (see Almlund et al., 2011 for a review of possible alternatives), it does include a series of questions on locus of control, self-esteem and attitudes to work asked at age 15 .

\footnotetext{
${ }^{2}$ We do not consider the complex array of vocational training courses that less academic students can take from 16 to 18 .

${ }^{3}$ We group the following subjects under "Science": Biology, Chemistry, Physics (and any combination of two of these three subjects), Environmental Science, Psychology (as a Science), Science for Public Understanding, Science: technology, Zoology, Meteorology, Engineering Science, Other Science.
} 
Locus of control refers to individual beliefs about whether life events are mostly internally or externally determined (Rotter, 1966). People with an external locus of control believe that what happens in life is largely determined by events beyond their control, while individuals with internal locus of control generally believe that life events are mostly caused by their own decisions and behaviours. We measure locus of control using children's responses to six questions (see the Appendix for details). We follow the previous literature in the field (see for example Cobb-Clark et al., 2014 and Piatek and Pinger 2010) and use factor analysis to create indices of internal and external locus of control. Children are coded as external if they have a score in the top quartile of the distribution of the external index, derived from factor analysis (see Schurer, 2014). We also examine the robustness of this definition, by classifying children as external if they have a score in the top third or half of the distribution of the external index (see Caliendo et al., 2014). Self-esteem refers to an individual perception of her/his own value. LSYPE data includes two questions on selfesteem (see Appendix for details) asked at waves 2 and 4. We construct an indicator of low self-esteem equal to 1 if they have placed themselves in the most distressed category for one of the two questions at least once between the two waves (around $26 \%$ of the children in the sample) $)^{4}$.

Almlund et al. (2011) suggest that competence, dutifulness, self-discipline, perseverance and work-ethic are all facets of Conscientiousness. LSYPE includes four questions on working attitudes (see the Appendix for details) and we use factor analysis to create an index of work ethics. Children are coded as having high work ethics, if they have a score in the top quartile of the distribution of the index (see Schurer, 2014).

\footnotetext{
${ }^{4}$ Alternative/more restrictive indicators of low self-esteem were constructed to test the robustness of our estimates and results are available on request.
} 


\subsection{Other explanatory variables}

We estimate two versions of our model, one more parsimonious than the other. All of the variables we control for are, arguably, pre-determined variables - that is, not themselves influenced by personality traits. Our more parsimonious model only includes at-birth characteristics such as: birth-weight; whether the child was premature; ethnic background; sex of the child; and family characteristics such as marital status and age of the mother at birth. In the second model we include other family's characteristics (measured at wave 1) such as: child's or parent's disability, maternal education and employment status, whether the child lives in a single parent family, grandparents' education, family income and older siblings. One natural concern is that personality traits might be related with cognitive ability and mental health (see for example Judge et al. 2002, and Schurer 2014) and therefore our results could be picking up the effect of those variables, rather than personality traits per se. Our data does not include any measure of cognitive ability (e.g. IQ test or other psychometric assessments) and therefore we cannot control for this information in our model. LSYPE includes the General Health Questionnaire (GHQ) score, as a measure of youths' mental health. We run a sensitivity analysis of our second model including the GHQ score and main results are unchanged (results are available on request). However, we decided to follow the main literature in this area (see for example Coleman and Deleire, 2000; Heckman et al., 2006; Delaney et al., 2013; Lundberg, 2013) and not to include this measure in the preferred version of the model, as mental health is likely to be correlated with personality and therefore the GHQ score is likely to be endogenous.

Table 3 presents descriptive statistics on the outcome variables, broken down by personality traits. Individuals with external locus of control and low self-esteem seem less likely to perform well in their GCSE and A levels exams and to choose "core subjects” in their studies. On the other hand, children with a high level of work ethics seem to have better 
results both at GCSE and at A levels and to be more likely to continue with further education after GCSE.

Table 3 here.

We explore the possibility of heterogeneity in the effect of personality traits on children by socio-economic background and by various indicators of socio-economic disadvantage. We follow Ruhm (2008) and construct a multivariate indicator of socioeconomic status by regressing total family income on mother's age at birth, education, and marital status. Youths are classified as "advantaged” (“disadvantaged”) if they live in households that are above (below) the median prediction. This SES index simultaneously accounts for a larger number of determinants than simple income and possibly reduces the endogeneity problem.

\section{Estimation}

While we begin by using Ordinary Least Squares, to control for observable confounders, this is well known to lead to biased estimates of the causal effects because of neglected heterogeneity. The linear model can be written as:

$$
Y_{i}=\alpha+P_{i}^{\prime} \beta+X_{i}^{\prime} \gamma+\varepsilon_{i}
$$

where $Y_{i}$ represents educational outcomes (test scores in various subjects or subject choice at A levels), $P_{\mathrm{i}}$ ' is a vector of psychological traits (binary indicators of external locus of control, low self-esteem, and high work ethics) and $X_{\mathrm{i}}$ ' is a vector of child's and family's characteristics. We cannot, in this data, address the selection on unobservables problem because there is simply no quasi-experimental variation across our sample to exploit. However, we do try to lower the upper bound provided by OLS estimation, through the inclusion of a more detailed set of independent variables. Estimation by OLS could be biased if we are not controlling for variables that actually play an important role in determining test 
scores (the so-called omitted variable bias), or because of reverse causality (i.e change in personality because of particular results in test scores). However, previous literature has shown that personality traits tend to be quite stable after childhood (Cobb-Clark and Schurer, 2012 and 2013) and we are using personality traits collected at least one year before the test scores.

Secondly, we exploit propensity score matching that does not rely on functional form assumptions and restricts inference to samples where we can find overlap in the distribution of covariates across the treatment.

Standard OLS regression controlling linearly for the observable characteristics and personality traits may suffer from two potential sources of bias. First, if the true model were non-linear in terms of the characteristics, the OLS estimate of the effect of personality traits would be biased. Second, this regression constrains the impact to be homogeneous, i.e. the same for all individuals; if, by contrast, the effect varies according to some of the youths' characteristics, OLS will not, in general, recover the Average Treatment on Treated (ATT) effect. Both these biases are exacerbated if some children fall outside the so-called common support of the observables - that is, if there are children with some particular personality traits for whom there are no comparable children in the sample of those without that particular trait. If that is the case, OLS would be comparing non comparable children using linear extrapolation.

In contrast, propensity score matching does not rely on the same functional form assumptions of OLS and restricts inference to samples where we can find overlap in the distribution of covariates across the treatment.

PSM may be thought of as assuming the selection problem way because it relies on conditional independence that implies no selection on the unobservables conditional on the 
observables. On the other hand, matching methods have some desirable features: the observations used to estimate the causal effect are selected without reference to the outcome, as in a controlled experiment; it dominates other methods based on selection on observables (like OLS), thanks to its more convincing comparison of treated and control units; it offers interesting insights for a better understanding of the estimation of causal effects; and there is some (debated) evidence suggesting that it contributes to a reduction in the selection bias (see Dehejia and Wahba 2002, Dehejia 2005, and Smith and Todd 2004). At the very least, matching provides a convincing way to select the observations on which other estimation methods can be based. Matching attaches appropriate weights to the observations in the control group, so that the distribution of their observable characteristics is realigned to the treatment group.

Propensity Score Matching has also been used in various recent papers investigating the determinants of child well-being (see for example Ruhm, 2008, Berger et al., 2005, and Goodman and Sianesi, 2005) and the effect of personality traits (Caliendo et al., 2014). The idea of propensity score matching is to match children with different personality traits (for example, with and without low self-esteem) who are as comparable as possible in all other respects so that they have similar propensities to be treated. More specifically, we first estimate the conditional probability of having a specific personality trait, called the propensity score: such as having low self-esteem for each child, given our covariates. Then, estimated propensity scores are used to create a matched control group and for each treated child we find the comparison member with the closest propensity score. Non-matched individuals are dropped from the analysis. Our analysis is performed using psmatch2 and appropriate tests have been run, in order to compare covariate distributions across our 
matched groups to ensure that adequate balance has been obtained (results available in Appendix Table A1) ${ }^{5}$.

Lastly, we test our results using the methodology proposed by Altonji et al. (2005) (AET) that relies on using the selection on observable traits to provide information about the potential for selection on unobservable characteristics. This approach states that the part of an outcome $\left(Y_{i}\right)$ that is related to the observables has the same relationship with personality traits as the part related to the unobservables. It requires some strong assumptions (see Altonji et al., 2005 for the details and Chatterji et al., 2011 and Johnston et al., 2013 for applications of the methodology) but has the advantage of not relying on identifying variables. The AET approach is based on the estimation of a bivariate probit model without any identifying restrictions but with a constrained correlation coefficient. Identification comes from this restriction as well as from functional form (Altonji et al., 2005). Following the AET approach, if the observable determinants of an outcome are a random set of the complete set of determinants, then selection on observable characteristics will be equal to selection on unobservable characteristics. Altonji et al. (2005) show that we can consider the following bivariate probit model:

$$
\begin{gathered}
Y=\mathbf{1}\left(\alpha+\beta P+X^{\prime} \gamma+\varepsilon>0\right) \\
P=\mathbf{1}\left(Z^{\prime} \theta+u>0\right) \\
\left(\begin{array}{l}
u \\
\varepsilon
\end{array}\right) \sim N\left(\begin{array}{l}
0 \\
0
\end{array}\right)\left(\begin{array}{ll}
1 & \rho \\
\rho & 1
\end{array}\right)
\end{gathered}
$$

\footnotetext{
${ }^{5}$ Our approach is similar to Goodman and Sianesi (2005) and we use propensity score matching with the nearest neighbour method with replacement (as it has been shown to reduce bias relative to matching without replacement, see Dehejia and Wahba, 2002) and then used the common option, so that off-support observations are automatically dropped. Similar results were obtained with other matching methods.
} 
In this model, the parameter $\rho$ is not identified and we use the degree of selection on the observables as a guide. The idea that "selection on the observables is the same as the selection on unobservables" is formalised as:

$$
\frac{\operatorname{Cov}(P, \varepsilon)}{\operatorname{Var}(\varepsilon)}=\frac{\operatorname{Cov}\left(P, X^{\prime} \gamma\right)}{\operatorname{Var}\left(X^{\prime} \gamma\right)}
$$

This condition holds under the following assumptions: the elements of $\boldsymbol{X}$ are chosen randomly from the full set of variables that determine $Y$; and the number of observed and unobserved factors is large enough so that no element dominates the distribution of the outcome. These assumptions are very strong but, as argued in Altonji et al. (2005), weaker than the standard OLS assumption that $\operatorname{Cov}(X, \varepsilon)=0$. Following Altonji et al. (2005), we present estimates that maximise the likelihood imposing $\rho=\frac{\operatorname{Cov}\left(P^{\prime} \beta, P^{\prime} \gamma\right)}{\operatorname{Var}\left(P^{\prime} \gamma\right)}$ which is equivalent to condition (5).

Altonji et al. (2005) argue that if $\mathrm{X}$, the observable determinants of $Y$, are a random sample of the complete set of determinants, selection on observable characteristics should be equal to selection on unobservable characteristics. In practice, as noted in Altonji et al (2005) there are reasons to believe that the relationship between the unobservables and any potentially endogenous treatment will be weaker than the relationship between the observables and the treatment. For instance, the set of independent variables $\mathrm{X}$ has been selected with the idea of reducing bias, rather than at random, and therefore the estimates obtained under this assumption could be considered a lower bound of the true effect.

\section{Results}

The results from the estimation of the effect of personality traits on high school results by subject are presented in Tables 4, 5, 6 and 7. Tables 4 and 5 present results from OLS and Probit models, where all three personality traits are included in the estimation at the same 
time. Personality traits have a strong ad significant effect on school performance, especially at GCSE level. External locus of control decreases chances of good results in GCSE Results in all subjects by about 20 percentage points - p.p and results are very similar across OLS and Probit specifications of Model 2. It also decreases chances of taking A levels by about 15 p.p. and performance in A levels in English, Mathematics and Science (by about 7 points). High work ethics have a positive effect on school performance and increases chances of doing well in GCSE exams and taking A levels by about 5-6 p.p. It also increases scores in A levels in Mathematics (+ 6 points) and Science (+ 14 points). Results from specifications where we include each personality trait separately are not presented for parsimony but are very similar. On the basis of the stability of our results we feel justified in examining the effects of each trait separately in our subsequent PSM and AET analysis (see Table 7 and 8).

In our discussion, we will focus on the results from PSM estimation of Model 2 (see Table 7), as this is our preferred specification and results do not vary significantly from Model 1 to Model 2 (as showed by the tests reported in Table 4).

Figures 1 and 2 show the distribution of propensity scores across treatment and control groups. Both graphs show that there is sufficient overlap between the treatment and control groups.

\section{Figure 1 here}

Figure 2 here

\section{Table 4 here}

\section{Table 5 here}

Results from Table 7 confirm that personality has a notable effect on high school performance and on subject choices. In particular, individuals with external locus of control are less likely to have good results in test scores at age 16, and they are less likely to study for 
A levels exams (-14 p.p.), and less likely to choose Mathematics (- 7 p.p) , or Science (-11 p.p) as their A levels subjects. At A level, the number of "facilitating subjects" (English, Mathematics, Sciences, History, Geography, and Languages) chosen by these students is likely to be lower than the one selected by their peers without external locus of control. Their grades also tend to be lower, both for English and maths at GCSE level and for mathematics and science at A level (by about 8 to 11 points, or 15\% of a standard deviation). Low selfesteem has a similar effect on performance and subject choices, but to a smaller extent. On the other hand, students with high work ethics tend to perform better in GCSE tests, are more likely to take A levels (by about 5 p.p. or $11 \%$ of a standard deviation), choose core subjects for their exams and perform better in mathematics and science (+ 8 to +14 p.p. or $15 \%$ to 19\% of a standard deviation). Results from balancing tests for PSM model are reported and discussed in Appendix Table A1.

The results from Probit, PSM and AET estimation are generally consistent with those reported from OLS estimation, with slightly lower effects, on average, reported from PSM estimation. Nonetheless the degree to which PSM tightens the OLS bound is surprisingly small. OLS seems to do a reasonable job despite our reservations. Interestingly, in all different specifications of model 2, external locus of control and high work ethics seem to have a stronger impact on results in mathematics and science, than in English, especially at A-level. It is possible that these personality traits, which are closely related to motivation and hard-working attitude impact more on these subjects, while other non-cognitive traits (such as, for example, creativity or openness to experience) may have a stronger impact on performance in English.

One possible explanation for the negative effects of external locus of control is that external individuals tend to think that their choices have less impact on their future, which they believe are mostly driven by luck and external circumstances. As a consequence, these 
children are less likely to put a strong effort in their school work, as they do not believe this will impact their future. This affects their performance and their chances to achieve high results in their education. Low self-esteem may have a similar but smaller effect. Children with low self-esteem struggle to see themselves as valuable, and this could affect their aspirations and effort to achieve their potential, which in turn will affect their school results and their choices related to further education. On the other hand, it is possible that individuals with external locus of control or low self-esteem are more likely to come from families where education is not valued, or they suffer from chronic stressor and are less able to concentrate, and this affects their performance at school.

Further, a high level of work ethics could have a positive effect on test scores and subject choices because students who are conscientious with their school work and show a rigorous attitude could be more likely to perform well at GCSE level and to be willing to continue with their education. They are also more likely to invest their time and energy in choosing core subjects and perform well in mathematics, and science. It is also possible that they come from families where hard-working attitude is valued more and therefore they are more likely to put more effort in their school work.

Our findings are consistent with previous literature from psychology and economics. For example, Almlund et al., 2011 discuss findings from various studies showing that conscientiousness has very strong associations with course grades, which seems almost as large as those between grades and cognitive ability (see for example Poropat, 2009).

In Table 6 we split the results by socio-economic status, and present a test of the differences between results in the two groups. Interestingly, personality has a stronger effect on performance at GCSE level for children who come from low socio-economic backgrounds. The chances of getting 5 or more GCSE passes improve by around 10 p.p. for 
disadvantaged children if they have high work ethics, and similar effects are found for performance in English and mathematics at GCSE level. The negative effect of external locus of control is found for both socio-economic groups, but it is stronger for students with a disadvantaged background (around -25 p.p) and the differences are significant. External locus of control also plays a negative role in the performance of disadvantaged youths who take Alevel English, while high work ethics seems to be more strongly rewarded for youths from advantaged socio-economic status who undertake A levels in Mathematics and Science. However, testing differences in results for A-levels is particularly complicated as the number of individuals who choose to complete this exam is small, especially among children who come from disadvantaged families.

\section{Table 6 here}

\section{Table 7 here}

These differences are not entirely unexpected: children from advantaged socioeconomic backgrounds are more likely to receive positive stimulation in the home environment and to have parents who closely supervise their school work. They are also more likely to continue their education after GCSE because of the higher expectations of their families. Therefore, the role of personality traits is less important and is partially outweighed by family resources. On the other hand, the results for students from disadvantaged families seem to be more affected by positive or negative personality traits. It is likely that individual non-cognitive skills will have more impact in families where the children receive less support and stimulation through their education. One obvious concern in performing this type of analysis if that growing up in a deprived socio-economic environment may directly affect personality of young people. Previous research has investigated whether, for example, welfare receipt can influence non-cognitive traits (Baron and Cobb-Clark, 2010) who investigate this issue using a model in which locus of control is regressed against a series of 
measures of socio-economic disadvantage and their results show little evidence that young disadvantaged have a more external locus of control once family demographics and background characteristics are taken into account.

Lastly, in Table 8 we present results from the empirical strategy proposed by Altonji et al. (2005) and applied by Chatterji et al. (2011), which does not rely on problematic identifying assumptions. The first part of the AET method consists in varying the level of correlation between unobservables determining personality traits and outcomes and determining whether the effect of personality is sensitive to these variations. The first column in table 8 column reports estimates identical to a standard univariate probit (imposing no correlations between the unobservables determining outcomes and personality traits ${ }^{6}$ ), while the other columns report estimates of the effect of personality traits on various outcomes from bivariate probit models imposing increasingly stronger levels of correlations between error terms. The true level of correlation between the errors is unknown. However, we follow Johnston et al. (2013) and we vary $\rho$ between 0 and the correlations between the outcomes and each specific personality traits in a linear model without other covariates. For example, it is reasonable to assume that unobserved factors will affect external locus of control and school outcomes in opposite directions. The coefficient of external locus in a linear model where we regress the probability of obtaining at least 5 GCSE with grade between $A^{*}$ and C against it with no other covariates is equal to -0.29 and therefore we vary $\rho$ between 0 and 0.30 .

In the first part of Table 8, as expected, increasing the negative error correlation decreases the estimated effect of external locus of control on all outcomes. However, the effects on performance at GCSE level remain statistically significant and negative even when moderate levels of negative selection are imposed (the effect on the chances of sitting A

\footnotetext{
${ }^{6}$ The results are slightly different from the ones from a probit model reported in Table 5 because in the AET test we consider one personality trait at a time, in order to construct the bivariate probit model.
} 
levels become insignificant only when $\rho$ is set to - 0.30). The effects on the performance in $\mathrm{A}$ level subjects are more sensitive to the imposed level of correlation. Even small amounts of negative correlation between the unobservables make the effect of external locus of control statistically insignificant. However, as already noticed, the number of children taking A levels is significantly smaller than the ones taking GCSE and the small sample size might be affecting the results. The last column shows results from the second part of the AET method, i.e. the bivariate probit model, where selection on observables is used to set the level of selection on unobservables. When selection on observables is set equal to selection on unobservables, the effect of external locus of control becomes insignificant (and $\rho$ varies between -0.35 and -0.40 for the estimation on GCSE performance). In the second part of Table 8, we progressively increase the levels of positive correlation in the estimation of the effect of high work ethics of school performance. The effects on GCSE performance and on the probability to take A levels remain positive and statistically significant when moderate level of selection are introduced, while results on performance at A levels are more sensitive to selection. However, the effect of work ethics on the probability of taking A-levels in Science remain unchanged. The positive effects of high work ethics persist when selection on observables is set equal to selection on unobservables.

Lastly, we vary the level of negative correlation between the error terms in the estimation of the effect of low self-esteem. Here the results are sensitive to the level of negative correlation imposed but most of the effect on GCSE performance persist when selection on observable is equal to selection on unobservables (and $\rho$ assumes slightly positive values, indicating possible positive, even if very moderate, correlation between the unobservables affecting the impact of low self- esteem on school performance). 
In general, we believe that results from the AET test confirm our original hypothesis of significant effects of personality on school performance, and especially the positive impact of high work ethics.

\section{Table 8 here}

As shown in Appendix Table A2, the effects of personality traits are comparable with the effect of other important variables, such as family income, presence of older siblings, or growing up in a single parent household. The results from Appendix Table A2 are highly consistent with our expectations and with previous literature on education. Generally, children from high income and high education families perform better than their disadvantaged peers. Boys have worse results than girls at GCSE level and they are also less likely to take A-levels. However, they tend to have higher scores in Mathematics and Science when they do take A levels. Ethnic minorities (and especially children with an Asian background) perform well at all exams while children from single mother households, those whose mums were very young at birth, or those who grow up with a disability or a disable parent tend to have worse results both at age 16 and 18.

\section{Conclusion and Discussion}

This paper has highlighted the effect of personality on performance and subjects' choice in high school. We used the Longitudinal Study of Young People in England, which is a rich source of information on English teen-agers and can be linked to the National Pupil Database, in order to get detailed information on school outcomes. We find that personality traits have a significant effect on test scores at age 16-17 and 17-18 and this effect is particularly relevant for children who come from disadvantaged socio-economic backgrounds. The size of the effect is notable and is comparable to other important variables, such as family income, presence of older siblings, or growing up in a single parent household. 
Our analysis is performed using Ordinary Least Squares, Propensity Score Matching and the methodology proposed by Altonji et al. (2005) which relies on using the selection on observable traits to provide information about the selection on unobservable characteristics. We make extensive use of the information contained in LSYPE and increase our set of independent variables, in order to control for wider factors affecting both school outcomes and personality traits. Our results are stable over the two different specifications of our model. Moreover, Propensity Score Matching and AET allow us to better compare a group of children who did not have specific personality traits with observationally similar children who have those characteristics, given our independent variables.

The paper provides further evidence of the positive (negative) effects of high work ethics (external locus of control and low self-esteem) on cognitive outcomes that are well known to have important effects on lifecycle living standards. In particular, we show that external locus of control and high work ethics have strong and opposite effects on performance in Mathematics and Science.

A variety of interventions have been suggested that exploit the early malleability of personality to improve long term outcomes. Selective personality-targeted interventions that focus on specific personality traits as risk factors for negative and harmful behaviours have recently been shown to be more effective than universal prevention programs (see for example Conrod et al., 2010, Foxcroft and Tsertsvadze, 2011, Conrod et al., 2013). In the UK, an example of these policies is SEAL (Social and Emotional Aspects of Learning), a voluntary program designed to develop the social and emotional skills of all school pupils in the areas of self-awareness, managing feelings, empathy, motivation and social skills. SEAL is currently being implemented in around $90 \%$ of primary schools and $70 \%$ of secondary schools. Various evaluations of SEAL have been conducted. Hallam, Rhamie and Shaw (2006) concluded that primary SEAL "had a major impact on children's well-being, 
confidence, social and communication skills, relationships, including bullying, playtime behaviour, pro-social behaviour and attitudes towards schools”. The evaluations of a number of existing policies have shown that changing personality is possible and interventions are useful, especially when they target young children and adolescents. We believe that our study shows some of the ultimate benefits of these programs, which span a wide range of achievements, which might have important long lasting consequences on individuals' lives and society as a whole.

The results here strongly suggest that there is a potential for policies that exploit possible changes in personality to promote positive educational choices and achievements in adolescence - outcomes that are important determinants of long run living standards. 


\section{References}

Almlund, M., Lee Duckworth, A., Heckman, J.J., Kautz T. (2011). Personality Psychology and Economics. In Handbook of the Economics of Education. Vol. 4, ed. Hanushek E.A., Machin S. Woessmann L., 1-181. Amsterdam: Elsevier.

Altonji, J.G., Elder, T., Taber, C. (2005). Selection on Observed and Unobserved Variables: Assessing the Effectiveness of Catholic Schools. Journal of Political Economy 113: 151-184.

Baron, J. D., Cobb-Clark, D. (2010). Are Young People's Educational Outcomes Linked to their Sense of Control? IZA Working Paper no. 4907.

Berger, L.M., Hill, J., Waldfogel, J. (2005). Maternity Leave, Early Maternal Employment and Child Health and Development in the US. Economic Journal, 115, 29-47.

Borghans, L., Lee Duckworth, A., Heckman, J., Ter Weel, B. (2008). The Economics and Psychology of Personality Traits. Journal of Human Resources, 43, 972-1059

Caliendo, M., Cobb-Clark, D., Uhlendorff, A. (2014). Locus of Control and Job Search Strategies. Review of Economics and Statistics, forthcoming.

Carneiro, P., Heckman, J. J. (2003). Human Capital Policy. In J. J. Heckman, A. B. Krueger, \& B. M. Friedman (Eds.), Inequality in America: What role for human capital policies? Cambridge, Mass: MIT Press.

Carneiro, P., Crawford, C., Goodman, A. (2007). The Impact of Early Cognitive and NonCognitive Skills on Later Outcomes, CEE DP 92.

Cebi, M. (2007). Locus of Control and Human Capital Investment Revisited. Journal of Human Resources, 42, 919-932.

Chamorro-Premuzic, T., Furnham, A. (2003). Personality Predicts Academic Performance: Evidence from Two Longitudinal University Samples. Journal of Research in Personality, 37, 319-38.

Chatterji, P., Alegria, M., Takeuchi, D., 2011. Psychiatric disorders and labor market outcomes: evidence from the National Comorbidity Survey-Replication. Journal of Health Economics, 30, 858-868.

Cobb-Clark, D., Kassenboehmer, S.C., Schurer, S. (2014). Healthy Habits: The Connection between Diet, Exercise, and Locus of Control. Journal of Economic Behavior and Organization, 98, 1-28.

Cobb-Clark, D., Schurer, S. (2012). The stability of the Big-Five personality traits. Economics Letters, 115, 11-15.

Cobb-Clark D., Schurer S. (2013). Two Economists' Musings on the Stability of Locus of Control. The Economic Journal, 123, 358-400.

Coleman, M., DeLeire, T. (2003). An Economic Model of Locus of Control and the Human Capital Investment Decision. The Journal of Human Resources, 38, 701-721.

Conrod, P. J., Castellanos-Ryan, N., Strang, J. (2010). Brief, Personality-Targeted Coping Skills Interventions and Survival as a Non-Drug User over a 2-Year Period During Adolescence. Archives of General Psychiatry, 67, 85-93. 
Conrod, P.J., O’Leavy Barret, M.A., Newton, N., Topper, L., Castellanos-Ryan, N., Mackie, C., Girard, A. (2013). Effective of a Seective, Personality -Targeted Prevention Program for Adolescent Alcohol Use and Misuse. Journal of American Medical Association - Psychiatry, 70, 334-342.

Cortes, K., Goodman, J., Nomi, T. (2013). Intensive Math Instruction and Educational Attainment: Long-Run Impacts of Double-Dose Algebra, Harvard Kennedy School Faculty Research Working Paper Series RWP13-009.

Crawford, C., Cribb, J. (2013) Reading and Mathematics Skills at Age 10 and Earnings in Later Life: A Brief Analysis Using the British Cohort Study. Centre for Analysis of Youth Transitions (CAYT) Impact Study: REP03.

Dehejia, R.H., Wahba, S. (2002). Propensity Score-Matching Methods for Non-Experimental Causal Studies. The Review of Economics and Statistics, 84, 151-61.

Dehejia, R.H. 2005. Practical Propensity Score Matching: a Reply to Smith and Todd. Journal of Econometrics, 125, 355-364.

Delaney, L., Harmon, C., Ryan, M. (2013). The Role of Noncognitive Traits in Undergraduate Study Behaviours. Economics of Education Review, 32, 181-195.

Dolton, P.J., Vignoles, A. (2002). Is a Broader Curriculum Better? Economics of Education Review, 21, 415-429.

Duckworth, K., Schoon, I. (2010). Progress and Attainment During Primary School: the Roles of Literacy, Numeracy and Self-Regulation. Longitudinal and Life Course Studies, 1, 223-240.

Duckworth, A., Seligman, M. (2005). Self-Discipline Outdoes IQ in Predicting Academic Performance of Adolescents, Psychological Science, 16, 939-944.

Duncan, G.J., Dowsett, C.J., Claessens, A.,Mugnuson, K., Huston, A.C., Klebanov, P.,Pagani, L.S., Feinstein, L., Engel, M., Brooks- Gunn, J., Sexton, H., Duckworth K., Japel, C. (2007), School Readiness and Later Achievement. Developmental Psychology, 43, 1428-1446.

Foxcroft D.R., Tsertsvadze A. (2011). Universal School-based Prevention Programs for Alcohol Misuse in Young People. Cochrane Database of Systematic Reviews 5, doi.

Goldberg, L.R., Sweeney, D. Merenda, P.F., \& Hughes, J.E. (1998). Demographic variables and personality: The effects of gender, age, education, and ethnic/racial status on selfdescriptions of personality attributes. Personality and Individual Differences, 24, 393403.

Goodman A., Sianesi B. (2005). Early Education and Children's Outcomes: How Long Do the Impacts Last? Fiscal Studies, 26, 513-548.

Hallam, S., Rhamie, J., Shaw, J. (2006). Evaluation of the Primary Behaviour and Attendance Pilot. Research Report RR717. Nottingham: DfES Publications

Heckman, J J., Masterov, D. (2007). The Productivity Argument for Investing in Young Children. Review of Agricultural Economics, 29, 446-93.

Heckman, J. J., Moon, S. H., Pinto, R., Savelyev, P. A., Yavitz, A. (2010). The Rate of Return to the HighScope Perry Preschool Program. Journal of Public Economics, 9, 114-128. 
Heckman J.J., Rubinstein Y.(2001).The Importance of Noncognitive Skills: Lessons from the GED Testing Program. American Economic Review, 91, 145-149

Heckman J.J., Stixrud, J., Urzua, S. 2006. The Effects of Cognitive and Noncognitive Abilities on Labor Market Outcomes and Social Behavior. Journal of Labor Economics 24: 411-482.

Joensen, J.S., Nielsen, H. S. (2009). Is there a Causal Effect of High School Math on Labor Market Outcomes? Journal of Human Resources, 44, 171-198.

Johnston, D., Schurer, S., Shields, M. (2013). Exploring the intergenerational persistence of mental health: Evidence from three generations. Journal of Health Economics, 32, 1077-1089.

Judge, T.A., Erez, A., Bono, J.E., Thoresen, C.J. (2002). Are measures of self-esteem, neuroticism, locus of control, and generalized self-efficacy indicators of a common core construct? Journal of Personality and Social Psychology, 83, 693-710.

Kalil, A., \& Khalid, S. (2011, April). “Non-cognitive skills and educational attainment” Paper presented at the Annual Meeting of the Population Association of America, Washington, D.C.

Lundberg, S. (2013). The College Type: Personality and Educational Inequality. Journal of Labor Economics, 31: 421-441.

OECD (2012) Education at A Glance, OECD.

Piatek R., Pinger P. 2010. Maintaining (Locus of) Control? Assessing the Impact of Locus of Control on Education Decisions and Wages. IZA Discussion Paper 5289.

Poropat, A.E., (2009). A Meta-Analysis of the Five-Factor Model of Personality and Academic Performance. Psychological Bullettin, 135, 322-338.

Ross, C. E., Broh, B.A. (2000). The roles of self-esteem and the sense of personal control in the academic achievement process. Sociology of Education, 73, 270- 284.

Rotter, J. (1966). Generalized Expectancies for Internal Versus External Control of Reinforcement, Psychological Monographs, 80, 1-28.

Ruhm C.J. (2008). Maternal Employment and Adolescent Development. Labour Economics, 15, 958-983.

Schurer, S. (2014). Bouncing back from health shocks: Locus of control, labour supply, and mortality. IZA Discussion Paper 8203.

Silles, M. (2010). Personality, Education and Earnings. Education Economics, 18, 131-151.

Smith J., Todd P., 2004. Does Matching Overcome Lalonde’s Critique of Nonexperimental Estimators. Journal of Econometrics 125: 305-353.

Wang, L.-Y., Kick, E., Fraser, J., Burns, T.J. (1999). Status Attainment in America: The Roles of Locus of Control and Self-Esteem in Educational and Occupational Outcomes. Sociological Spectrum, 19, 281- 298. 


\section{Tables}

Table 1 Summary of main findings in the literature on the effects of childcare on children outcomes (in alphabetical order)

\begin{tabular}{|c|c|c|c|}
\hline Paper & Data & Method & Main findings \\
\hline $\begin{array}{l}\text { Baron and Cobb-Clark } \\
\text { (2010) }\end{array}$ & Youth in Focus & $\begin{array}{l}\text { OLS, Probit } \\
\text { Ordered probit }\end{array}$ & $\begin{array}{l}\text { A standard deviation increase in locus of control increases the probability of high school } \\
\text { graduation by } 4.5 \text { p.p. }\end{array}$ \\
\hline $\begin{array}{l}\text { Coleman and Deleire } \\
\text { (2003) }\end{array}$ & NELS & Probit & $\begin{array}{l}\text { A standard deviation increase in youths' sense of control results in a } 2 \text { to 3pp increase in the } \\
\text { probability of completing high school. }\end{array}$ \\
\hline Cebi (2007) & NLSY & Probit & A standard deviation increase in locus of control increases hourly wages by 2.1 percent. \\
\hline Borghans et al. (2008) & $\begin{array}{l}128 \text { students } \\
\text { from Maastrict } \\
\text { University }\end{array}$ & Experimental analysis & $\begin{array}{l}\text { Subjects with favorable personality traits such as high performance-motivation and an internal } \\
\text { locus of control perform relatively well in the absence of rewards. }\end{array}$ \\
\hline Heckman et al., 2006 & NLSY79 & Structural model & Non-cognitive skills affect years of schooling and college performance. \\
\hline Delaney et al., 2013 & $\begin{array}{l}\text { Irish University } \\
\text { Study }\end{array}$ & $\begin{array}{l}\text { OLS with a broad set } \\
\text { of covariates }\end{array}$ & $\begin{array}{l}\text { A standard deviation increase in students' conscientiousness increases lecture } \\
\text { attendance by approximately } 7.4 \text { percent; and increases study time by almost two hours }\end{array}$ \\
\hline Carneiro et al., 2007 & NCDS58 & OLS & $\begin{array}{l}\text { A standard deviation increase in social adjustment score at age } 11 \text { increases the probability to } \\
\text { stay at school after age } 16 \text { by } 4 \text { p.p. and the probability of having a degree by } 2 \text { p.p. }\end{array}$ \\
\hline Lundberg, 2013 & $\begin{array}{l}\text { NLSAH-Add } \\
\text { Health }\end{array}$ & LPM & $\begin{array}{l}\text { Conscientiousness has no significant impact on the education of disadvantaged men, while } \\
\text { openness to experience has an effect on chances of college graduation only for less-advantaged } \\
\text { men and women. }\end{array}$ \\
\hline Coneus et al., 2009 & GSOEP & Probit and IV & $\begin{array}{l}\text { A standard deviation difference in noncognitive skills (locus of control) is related to a } \\
\text { dropout probability that is } 2.2 \text { to } 3.7 \text { percentage points lower. }\end{array}$ \\
\hline Silles, 2010 & NCDS & OLS & Social maladjustment is associated with worst educational attainment (test score at age 16) \\
\hline Kalil et al., 2010 & NLSY97 & $\begin{array}{l}\text { OLS and Blinder } \\
\text { Oaxaca decomposition }\end{array}$ & $\begin{array}{l}\text { A standard deviation increase in self-efficacy increases educational attainment (measured in } \\
\text { years of education and college attendance) by } 0.04 \text { standard deviations }\end{array}$ \\
\hline
\end{tabular}


Table 2 - Outcomes

Test Scores

Has 5 or more GCSE with $A^{*}$-C

Has achieved A*-C in GCSE Mathematics

Has achieved A*-C in GCSE English

Has A levels

A level points

Has A level - Mathematics

A level points - Mathematics

Has A level - Science

A level points - Science

Has A level - English

A level points - English

No. facilitating subjects

Geography, Languages)
Variable

Binary (1/0)

Binary (1/0)

Binary (1/0)

Binary $(1 / 0)$

In points

Binary $(1 / 0)$

In points

Binary (1/0)

In points

Binary (1/0)

In points

(Maths, Science, English, History, Number of subjects

(from 0 to 6) 
Table 3 - Descriptive statistics of outcome variables by locus of control, self-esteem and work ethics

Whole sample

Has 5 + GCSE with A*-C - \%

Has GCSEA*-C in English - \%

Has GCSEA*-C in Maths - \%

Has A levels - \%

Points in A levels - mean (sd)

Has A levels - Maths - \%

Points in A levels Maths - mean (sd)

Has A levels - Science - \%

Points in A levels Science - mean (sd)

Has A levels - English - \%

Points in A levels English - mean (sd)

No. facilitating subjects (Maths, Science, English,

History, Geography, Languages) mean (sd)

\section{External}

Low Self-Esteem

32.8
45.1
40.6
22.4
$.72(127.1)$
3.2
$8.5(53.0)$
4.8
$.33(70.2)$
7.2
$.55(24.8)$
$0.9(0.8)$

53.0

67.3

58.1

38.8

$260.26(126.3)$

$260.9(132.7)$

8.9

$113.36(52.1)$

12

$135.18(76.5)$

12

$92.48(28.9)$

$1.2(0.9)$

$0.9(0.8)$
111.7 (54.6)

10

129.62 (76.7)

12.7

90.56 (26.6)

$1.1(0.9)$
High Work ethics
63.7
74.8
69.3
47.4
11.3
16.1
14.8
$1.3(0.9)$

264.53 (138.5)

122.5 (57.6)

141.85 (76.4)

$97.12(29.0)$ 
Table 4 Effect of personality traits on high school performance and subjects' choice - OLS Estimation Results

\begin{tabular}{|c|c|c|c|c|c|c|c|c|c|c|c|}
\hline $\begin{array}{l}\text { 5+GCSE } \\
A^{*}-C\end{array}$ & $\begin{array}{l}\text { GCSE } \\
\text { A*-C } \\
\text { English }\end{array}$ & $\begin{array}{l}\text { GCSE } \\
\text { A*-C } \\
\text { Maths }\end{array}$ & A levels & $\begin{array}{l}\text { A levels } \\
\text { points } \\
\text { score }\end{array}$ & $\begin{array}{l}\text { A level } \\
\text { in } \\
\text { Maths }\end{array}$ & $\begin{array}{l}\text { A level } \\
\text { points } \\
\text { in } \\
\text { Maths }\end{array}$ & $\begin{array}{l}\text { A levels } \\
\text { in } \\
\text { Science }\end{array}$ & $\begin{array}{l}\text { A level } \\
\text { points in } \\
\text { Science }\end{array}$ & $\begin{array}{l}\text { A levels } \\
\text { in } \\
\text { English }\end{array}$ & $\begin{array}{l}\text { A level } \\
\text { points in } \\
\text { English }\end{array}$ & $\begin{array}{l}\text { No. facil. } \\
\text { subjects }\end{array}$ \\
\hline
\end{tabular}

\begin{tabular}{|c|c|c|c|c|c|c|c|c|c|c|c|c|}
\hline \multicolumn{13}{|l|}{ Model 1} \\
\hline External & -0.272 & -0.273 & -0.263 & -0.204 & -34.618 & -0.063 & -8.027 & -0.068 & -7.955 & -0.050 & -6.402 & -0.255 \\
\hline $\begin{array}{l}\text { Locus of } \\
\text { Control }\end{array}$ & $(0.015)^{* * *}$ & $(0.014)^{* * *}$ & $(0.014)^{* * *}$ & $(0.015)^{* * *}$ & $(8.356)^{* * *}$ & $(0.024)^{* *}$ & $(3.152)^{* *}$ & $(0.027)^{* *}$ & $(4.478)^{*}$ & $(0.027)^{* * *}$ & $(2.695)^{* * *}$ & $(0.057)^{* * *}$ \\
\hline High Work & 0.067 & 0.051 & 0.048 & 0.063 & 6.884 & 0.021 & 5.703 & 0.077 & 13.313 & -0.017 & 0.136 & 0.146 \\
\hline Ethics & $(0.015)^{* * *}$ & $(0.014)^{* * *}$ & $(0.015)^{* * *}$ & $(0.015)^{* * *}$ & (6.626) & (0.019) & $(2.500)$ & $(0.022)^{* * *}$ & $(3.552)^{* * *}$ & $(0.021)$ & (2.138) & $(0.045)^{* * *}$ \\
\hline Low Self- & -0.001 & 0.016 & -0.025 & 0.011 & 2.786 & -0.047 & -5.147 & -0.053 & -9.096 & 0.049 & 3.998 & -0.072 \\
\hline Esteem & $(0.014)$ & $(0.013)$ & $(0.014)^{*}$ & $(0.014)$ & (6.647) & $(0.019)^{* *}$ & $(2.508)^{* *}$ & $(0.022)^{* *}$ & $(3.563)^{* *}$ & $(0.021)^{* * *}$ & $(2.144)^{* * *}$ & $(0.045)$ \\
\hline $\begin{array}{l}\text { F stat } \\
\text { (p-value) }\end{array}$ & $\begin{array}{l}62.83 \\
(0.00) \\
\end{array}$ & $\begin{array}{l}74.30 \\
(0.00) \\
\end{array}$ & $\begin{array}{l}56.75 \\
(0.00) \\
\end{array}$ & $\begin{array}{l}42.96 \\
(0.00) \\
\end{array}$ & $\begin{array}{c}8.62 \\
(0.00) \\
\end{array}$ & $\begin{array}{l}13.11 \\
(0.00) \\
\end{array}$ & $\begin{array}{l}11.49 \\
(0.00) \\
\end{array}$ & $\begin{array}{c}7.93 \\
(0.00) \\
\end{array}$ & $\begin{array}{c}6.97 \\
(0.00) \\
\end{array}$ & $\begin{array}{l}10.25 \\
(0.00)\end{array}$ & $\begin{array}{c}9.11 \\
(0.00) \\
\end{array}$ & $\begin{array}{c}9.24 \\
(0.00) \\
\end{array}$ \\
\hline \multicolumn{13}{|l|}{ Model 2} \\
\hline $\begin{array}{l}\text { External } \\
\text { Locus of } \\
\text { Control }\end{array}$ & $\begin{array}{c}-0.218 \\
(0.014)^{* * *}\end{array}$ & $\begin{array}{c}-0.221 \\
(0.013)^{* * *}\end{array}$ & $\begin{array}{c}-0.210 \\
(0.014)^{* * *}\end{array}$ & $\begin{array}{c}-0.153 \\
(0.014)^{* * *}\end{array}$ & $\begin{array}{c}-33.198 \\
(8.045)^{* * *}\end{array}$ & $\begin{array}{c}-0.059 \\
(0.025)^{* *}\end{array}$ & $\begin{array}{c}-7.464 \\
(3.143)^{* *}\end{array}$ & $\begin{array}{c}-0.066 \\
(0.028)^{* *}\end{array}$ & $\begin{array}{c}-7.329 \\
(4.436)^{*}\end{array}$ & $\begin{array}{l}-0.044 \\
(0.027)\end{array}$ & $\begin{array}{c}-5.932 \\
(2.708)^{* *}\end{array}$ & $\begin{array}{c}-0.236 \\
(0.057)^{* * *}\end{array}$ \\
\hline $\begin{array}{l}P \text { value for } \\
\text { test } M 1=M 2\end{array}$ & 0.00 & 0.00 & 0.00 & 0.00 & 0.57 & 0.38 & 0.32 & 0.54 & 0.48 & 0.07 & 0.21 & 0.13 \\
\hline High Work & 0.069 & 0.054 & 0.049 & 0.064 & 9.332 & 0.020 & 5.713 & 0.079 & 13.765 & -0.016 & 0.208 & 0.152 \\
\hline Ethics & $(0.015)^{* * *}$ & $(0.014)^{* * *}$ & $(0.015)^{* * *}$ & $(0.015)^{* * *}$ & (6.375) & $(0.020)$ & $(2.491)^{* *}$ & $(0.022)^{* * *}$ & $(3.515)^{* * *}$ & $(0.022)$ & $(2.146)$ & $(0.045)^{* * *}$ \\
\hline $\begin{array}{l}P \text { value for } \\
\text { test } M 1=M 2\end{array}$ & 0.80 & 0.74 & 0.86 & 0.89 & 0.24 & 0.64 & 0.98 & 0.59 & 0.54 & 0.45 & 0.23 & 0.57 \\
\hline Low Self- & -0.005 & 0.015 & -0.027 & 0.005 & 0.197 & -0.049 & -5.382 & -0.057 & -9.920 & 0.049 & 3.783 & -0.077 \\
\hline Esteem & $(0.014)$ & $(0.013)$ & $(0.014)^{* *}$ & $(0.014)$ & (6.384) & $(0.020)^{* *}$ & $(2.495)^{* *}$ & $(0.022)^{* * *}$ & $(3.521)^{* * *}$ & $(0.022)^{* *}$ & $(2.149)^{*}$ & $(0.045)^{*}$ \\
\hline $\begin{array}{l}P \text { value for } \\
\text { test } M 1=M 2\end{array}$ & 0.53 & 0.80 & 0.68 & 0.15 & 0.21 & 0.58 & 0.59 & 0.39 & 0.26 & 0.75 & 0.40 & 0.63 \\
\hline $\begin{array}{l}\text { N. } \\
\text { observations }\end{array}$ & 5,572 & 5,572 & 5,572 & 5,646 & 2,278 & 2,278 & 2,278 & 2,278 & 2,278 & 2,278 & 2,278 & 2,278 \\
\hline $\begin{array}{l}\text { F stat } \\
\text { (p-value) }\end{array}$ & $\begin{array}{r}58.99 \\
(0.00) \\
\end{array}$ & $\begin{array}{r}64.14 \\
(0.00) \\
\end{array}$ & $\begin{array}{l}52.23 \\
(0.00) \\
\end{array}$ & $\begin{array}{l}44.99 \\
(0.00) \\
\end{array}$ & $\begin{array}{r}12.49 \\
(0.00) \\
\end{array}$ & $\begin{array}{r}7.66 \\
(0.00) \\
\end{array}$ & $\begin{array}{c}7.04 \\
(0.00) \\
\end{array}$ & $\begin{array}{r}5.29 \\
(0.00) \\
\end{array}$ & $\begin{array}{r}6.29 \\
(0.00) \\
\end{array}$ & $\begin{array}{c}5.09 \\
(0.00) \\
\end{array}$ & $\begin{array}{c}4.62 \\
(0.00) \\
\end{array}$ & $\begin{array}{r}7.91 \\
(0.00) \\
\end{array}$ \\
\hline
\end{tabular}

Note: Standard errors are in brackets. * indicates that the underlying coefficient is significant at $10 \%$ level, ** at $5 \%$ and ***at $1 \%$. Additional variables included in the analysis are listed at p. 12. 
Table 5 Effect of personality traits on high school performance and subjects' choice - Probit Estimation Results

\begin{tabular}{|c|c|c|c|c|c|c|}
\hline SE A*-C & $\begin{array}{l}\text { GCSE A*-C } \\
\text { English }\end{array}$ & $\begin{array}{l}\text { GCSE A*-C } \\
\text { Maths }\end{array}$ & A levels & $\begin{array}{l}\text { A level in } \\
\text { Maths }\end{array}$ & $\begin{array}{l}\text { A levels in } \\
\text { Science }\end{array}$ & English \\
\hline
\end{tabular}

\begin{tabular}{|c|c|c|c|c|c|c|c|}
\hline Model 2 & & & & & & & \\
\hline $\begin{array}{l}\text { External } \\
\text { Locus of } \\
\text { Control }\end{array}$ & $\begin{array}{c}-0.650 \\
(0.043)^{* * *} \\
{[-0.255]}\end{array}$ & $\begin{array}{c}-0.676 \\
(0.044)^{* * *} \\
{[-0.246]}\end{array}$ & $\begin{array}{c}-0.609 \\
(0.042)^{* * *} \\
{[-0.234]}\end{array}$ & $\begin{array}{c}-0.506 \\
(0.045)^{* * *} \\
{[-0.180]}\end{array}$ & $\begin{array}{c}-0.229 \\
(0.095)^{* *} \\
{[-0.059]}\end{array}$ & $\begin{array}{c}-0.220 \\
(0.087)^{* *} \\
{[-0.071]}\end{array}$ & $\begin{array}{c}-0.139 \\
(0.086) \\
{[-0.045]}\end{array}$ \\
\hline $\begin{array}{c}\text { High Work } \\
\text { Ethics }\end{array}$ & $\begin{array}{c}0.212 \\
(0.045)^{* * *} \\
{[0.082]}\end{array}$ & $\begin{array}{c}0.199 \\
(0.048)^{* * *} \\
{[0.065]}\end{array}$ & $\begin{array}{c}0.159 \\
(0.046)^{* * *} \\
{[0.058]}\end{array}$ & $\begin{array}{c}0.193 \\
(0.044)^{* * *} \\
{[0.074]}\end{array}$ & $\begin{array}{c}0.054 \\
(0.069) \\
{[0.015]}\end{array}$ & $\begin{array}{c}0.234 \\
(0.065)^{* * *} \\
{[0.081]}\end{array}$ & $\begin{array}{c}-0.055 \\
(0.066) \\
{[-0.018]}\end{array}$ \\
\hline $\begin{array}{l}\text { Low Self- } \\
\text { Esteem } \\
\text { N. observations }\end{array}$ & $\begin{array}{c}-0.015 \\
(0.042) \\
{[-0.006]} \\
5,572\end{array}$ & $\begin{array}{c}0.051 \\
(0.045) \\
{[0.017]} \\
5,572\end{array}$ & $\begin{array}{c}-0.088 \\
(0.042)^{* *} \\
-[0.033] \\
5,572\end{array}$ & $\begin{array}{c}0.021 \\
(0.042) \\
{[0.074]} \\
5,646\end{array}$ & $\begin{array}{c}-0.197 \\
(0.074)^{* * *} \\
{[-0.053]} \\
2,278\end{array}$ & $\begin{array}{c}-0.183 \\
(0.067)^{* * *} \\
{[-0.060]} \\
2,278\end{array}$ & $\begin{array}{c}0.138 \\
(0.065)^{*} \\
{[0.047]} \\
2,278\end{array}$ \\
\hline
\end{tabular}

Note: Robust standard errors are in parentheses. Marginal effects are in brackets. * indicates that the underlying coefficient is significant at $10 \%$ level, $* *$ at $5 \%$ and $* * *$ at $1 \%$. Additional variables included in the analysis are listed at p. 12. 
Table 6 Effect of personality traits on high school performance and subjects' choice - OLS Estimation Results by socioeconomic status - Model 2

\begin{tabular}{|c|c|c|c|c|c|c|c|c|c|c|c|c|}
\hline & $\begin{array}{l}\text { 5+GCSE } \\
A^{*}-\mathrm{C}\end{array}$ & $\begin{array}{l}\text { GCSE } \\
\text { A*-C } \\
\text { English }\end{array}$ & $\begin{array}{l}\text { GCSE } \\
\text { A*-C } \\
\text { Maths }\end{array}$ & A levels & $\begin{array}{l}\text { A levels } \\
\text { points } \\
\text { score }\end{array}$ & $\begin{array}{l}\text { A level } \\
\text { in } \\
\text { Maths }\end{array}$ & $\begin{array}{l}\text { A level } \\
\text { points in } \\
\text { Maths }\end{array}$ & $\begin{array}{l}\text { A levels } \\
\text { in } \\
\text { Science }\end{array}$ & $\begin{array}{l}\text { A level } \\
\text { points in } \\
\text { Science }\end{array}$ & $\begin{array}{l}\text { A levels } \\
\text { in } \\
\text { English }\end{array}$ & $\begin{array}{l}\text { A level } \\
\text { points in } \\
\text { English }\end{array}$ & $\begin{array}{l}\text { No. facil. } \\
\text { subjects }\end{array}$ \\
\hline \multicolumn{13}{|c|}{ Advantaged Children } \\
\hline External & -0.184 & -0.168 & -0.142 & -0.171 & -33.861 & -0.042 & -5.616 & -0.061 & -6.324 & 0.010 & -2.040 & -0.204 \\
\hline $\begin{array}{l}\text { Locus of } \\
\text { Control }\end{array}$ & $(0.023)^{* * *}$ & $(0.021)^{* * *}$ & $(0.023)^{* * *}$ & $(0.023)^{* * *}$ & $(10.002)^{* * *}$ & $(0.031)$ & $(3.948)^{* * *}$ & $(0.032)$ & $(5.270)$ & $(0.035)$ & (3.288) & $(0.066)^{* * *}$ \\
\hline High & 0.033 & 0.017 & 0.022 & 0.045 & 23.394 & 0.029 & 9.440 & 0.105 & 20.045 & -0.004 & 3.015 & 0.175 \\
\hline Work & $(0.020)^{*}$ & $(0.017)$ & $(0.019)$ & $(0.022)^{* *}$ & $(8.638)^{* * *}$ & $(0.027)$ & $(4.014) * * *$ & $(0.030)^{* * *}$ & $(5.463)^{* * *}$ & $(0.028)$ & $(3.084)$ & $(0.059)^{* * *}$ \\
\hline Ethics & & & & & & & & & & & & \\
\hline Low Self- & 0.006 & 0.014 & -0.013 & -0.003 & 4.269 & -0.049 & -4.959 & -0.080 & -12.241 & 0.0769 & 6.324 & -0.103 \\
\hline Esteem & $(0.019)$ & $(0.016)$ & $(0.018)$ & $(0.021)$ & $(7.687)$ & $(0.024)^{*}$ & (3.332) & $(0.026)^{* * *}$ & $(4.491)^{* * *}$ & $(0.028)^{* * *}$ & $(2.823)^{* *}$ & $(0.055)^{*}$ \\
\hline \multicolumn{13}{|c|}{ Disadvantaged children } \\
\hline External & -0.233 & -0.250 & -0.249 & -0.131 & -30.88 & -0.079 & -9.622 & -0.068 & -7.925 & -0.132 & -12.343 & -0.294 \\
\hline $\begin{array}{l}\text { Locus of } \\
\text { Control }\end{array}$ & $(0.018) * * *$ & $(0.019)^{* * *}$ & $(0.019)^{* * *}$ & $(0.015)^{* * *}$ & $(12.992)^{* *}$ & $(0.031)^{* *}$ & $(3.16)^{* * *}$ & $(0.039)^{*}$ & $(5.782)$ & $(0.037)^{* * *}$ & $(3.407)^{* * *}$ & $(0.081)^{* * *}$ \\
\hline $\begin{array}{l}\text { P-value for } \\
\text { Test } \\
\text { adv=disadv }\end{array}$ & 0.10 & 0.005 & 0.00 & 0.16 & 0.85 & 0.39 & 0.42 & 0.88 & 0.83 & 0.006 & 0.03 & 0.39 \\
\hline $\begin{array}{l}\text { High } \\
\text { Work }\end{array}$ & $\begin{array}{c}0.098 \\
(0.020)^{* *}\end{array}$ & $\begin{array}{c}0.085 \\
(0.019)^{* * *}\end{array}$ & $\begin{array}{c}0.069 \\
(0.020)^{* * *}\end{array}$ & $\begin{array}{c}0.083 \\
(0.020)^{* * *}\end{array}$ & $\begin{array}{l}-7.179 \\
(9.796)\end{array}$ & $\begin{array}{l}-.0008 \\
(0.028)\end{array}$ & $\begin{array}{c}0.274 \\
(3.150)\end{array}$ & $\begin{array}{c}0.040 \\
(0.033)\end{array}$ & $\begin{array}{c}5.282 \\
(4.979)\end{array}$ & $\begin{array}{l}-0.018 \\
(0.032)\end{array}$ & $\begin{array}{l}-2.309 \\
(3.010)\end{array}$ & $\begin{array}{c}0.128 \\
(0.072)^{*}\end{array}$ \\
\hline Ethics & & & & & & & & & & & & \\
\hline $\begin{array}{l}\text { P-value for } \\
\text { Test } \\
\text { adv=disadv }\end{array}$ & 0.02 & 0.008 & 0.09 & 0.22 & 0.02 & 0.43 & 0.07 & 0.15 & 0.04 & 0.73 & 0.21 & 0.61 \\
\hline Low & -0.013 & 0.015 & -0.040 & 0.011 & -6.963 & -0.049 & -6.113 & -0.0212 & -6.767 & 0.017 & 0.685 & -0.021 \\
\hline Self- & (0.019) & (0.019) & $(0.019)^{* *}$ & $(0.017)$ & (10.185) & $(0.026)^{*}$ & $(2.870)^{* *}$ & $(0.034)$ & $(4.747)$ & $(0.035)$ & (3.242) & $(0.071)$ \\
\hline $\begin{array}{l}\text { Esteem } \\
\text { P-value for } \\
\text { Test } \\
\text { adv=disadv }\end{array}$ & 0.49 & 0.98 & 0.31 & 0.57 & 0.38 & 0.99 & 0.79 & 0.17 & 0.40 & 0.18 & 0.18 & 0.36 \\
\hline
\end{tabular}


Table 7 Effect of personality traits on high school performance and subjects' choice-PSM Estimation Results

\begin{tabular}{|c|c|c|c|c|c|c|c|c|c|c|c|c|}
\hline & $\begin{array}{l}\text { 5+GCSE } \\
A^{*}-\mathrm{C}\end{array}$ & $\begin{array}{l}\text { GCSE } \\
\text { A*-C } \\
\text { English }\end{array}$ & $\begin{array}{l}\text { GCSE } \\
\text { A*-C } \\
\text { Maths }\end{array}$ & A levels & $\begin{array}{l}\text { A levels } \\
\text { points } \\
\text { score }\end{array}$ & $\begin{array}{l}\text { A level } \\
\text { in } \\
\text { Maths }\end{array}$ & $\begin{array}{l}\text { A level } \\
\text { points in } \\
\text { Maths } \\
\end{array}$ & $\begin{array}{l}\text { A levels } \\
\text { in Science }\end{array}$ & $\begin{array}{l}\text { A level } \\
\text { points in } \\
\text { Science } \\
\end{array}$ & $\begin{array}{l}\text { A levels } \\
\text { in } \\
\text { English }\end{array}$ & $\begin{array}{l}\text { A level } \\
\text { points in } \\
\text { English }\end{array}$ & $\begin{array}{l}\text { No. facil. } \\
\text { subjects }\end{array}$ \\
\hline \multicolumn{13}{|l|}{ Model 2} \\
\hline External & -0.231 & -0.164 & -0.209 & -0.145 & -27.596 & -0.068 & -8.308 & -0.115 & -12.047 & -0.024 & -5.163 & -0.287 \\
\hline Locus of & $(0.021)^{* * *}$ & $(0.021)^{* * *}$ & $(0.021)^{* * *}$ & $(0.019)^{* *}$ & $(11.058)^{* *}$ & $(0.032)^{* *}$ & $(3.928)^{* * *}$ & $(0.037)^{* * *}$ & $(5.494)^{* * *}$ & $(0.036)$ & (3.469) & $(0.074)^{* * *}$ \\
\hline Control & 5,857 & 5,857 & 5,857 & 5,936 & 2,331 & 2,331 & 2,331 & 2,331 & 2,331 & 2,331 & 2,331 & 2,331 \\
\hline High & 0.108 & 0.073 & 0.091 & 0.052 & 21.714 & 0.052 & 7.972 & 0.092 & 14.095 & 0.001 & 1.931 & 0.228 \\
\hline Work & $(0.020)^{* * *}$ & $(0.018)^{* * *}$ & $(0.019)^{* * *}$ & $(0.019)^{* *}$ & $(8.517)^{* *}$ & $(0.024)^{* *}$ & $(3.094)^{* *}$ & $(0.026)^{* * *}$ & $(4.303)^{* * *}$ & $(0.026)$ & (2.613) & $(0.057)^{* * *}$ \\
\hline Ethics & 7,310 & 7,310 & 7,310 & 7,403 & 2,981 & 2,981 & 2,981 & 2,981 & 2,981 & 2,981 & 2,981 & 2,981 \\
\hline Low Self- & -0.065 & 0.007 & -0.078 & -0.016 & -2.002 & -0.048 & -4.296 & -0.055 & -7.572 & 0.033 & -0.024 & -0.099 \\
\hline \multirow[t]{2}{*}{ Esteem } & $(0.017)^{* * *}$ & $(0.016)$ & $(0.017)^{* * *}$ & $(0.016)$ & $(7.704)$ & $(0.022)^{* *}$ & (2.680) & $(0.025)^{* *}$ & $(3.941)^{*}$ & $(0.025)$ & (2.473) & $(0.053)^{*}$ \\
\hline & 8,293 & 8,293 & 8,293 & 8,414 & 3,215 & 3,215 & 3,215 & 3,215 & 3,215 & 3,215 & 3,215 & 3,215 \\
\hline
\end{tabular}

Note: Standard errors are in brackets. N. observations is reported under the standard errors. * indicates that the underlying coefficient is significant at $10 \%$ level, $* *$ at $5 \%$ and $* * *$ at $1 \%$. Additional variables included in the analysis are listed at p. 12. 
Table $8 \quad$ Sensitivity Analysis: Effect of personality traits on high school performance and subjects' choice given different assumptions on the correlations of disturbances in Bivariate Probit (AET Test)

\begin{tabular}{|c|c|c|c|c|c|c|c|c|}
\hline $\begin{array}{l}\text { External } \\
\text { Locus of } \\
\text { Control }\end{array}$ & $\rho=0$ & $\rho=-0.05$ & $\rho=-0.1$ & $\rho=-0.15$ & $\rho=-0.20$ & $\rho=-0.25$ & $\rho=-0.3$ & $\begin{array}{l}\rho \text { set such that } \\
\text { select on obs.= } \\
\text { select on unobs. }\end{array}$ \\
\hline $\begin{array}{l}\text { 5+GCSE A*- } \\
\text { C }\end{array}$ & $\begin{array}{c}-0.664 \\
(0.042)^{* * *}\end{array}$ & $\begin{array}{c}-0.578 \\
(0.042)^{* * *}\end{array}$ & $\begin{array}{c}-0.492 \\
(0.042)^{* * *}\end{array}$ & $\begin{array}{c}-0.406 \\
(0.041)^{* * *}\end{array}$ & $\begin{array}{c}-0.315 \\
(0.041)^{* * *}\end{array}$ & $\begin{array}{c}-0.235 \\
(0.041)^{* * * *}\end{array}$ & $\begin{array}{c}-0.134 \\
(0.040)^{* * *}\end{array}$ & $\begin{array}{c}0.016 \\
(0.039)\end{array}$ \\
\hline-0.296 & {$[-0.260]$} & {$[-0.227]$} & {$[-0.194]$} & {$[-0.161]$} & {$[-0.125]$} & {$[-0.093]$} & {$[-0.053]$} & {$[0.006] \rho=-0.38$} \\
\hline $\begin{array}{l}\text { GCSE A*-C } \\
\text { English }\end{array}$ & $\begin{array}{c}-0.675 \\
(0.0418)^{* * *}\end{array}$ & $\begin{array}{c}-0.589 \\
(0.041)^{* * *}\end{array}$ & $\begin{array}{c}-0.504 \\
(0.042)^{* * *}\end{array}$ & $\begin{array}{c}-0.419 \\
(0.041)^{* * *}\end{array}$ & $\begin{array}{c}-0.329 \\
(0.041)^{* * *}\end{array}$ & $\begin{array}{c}-0.250 \\
(0.041)^{* * *}\end{array}$ & $\begin{array}{c}-0.151 \\
(0.040)^{* * *}\end{array}$ & $\begin{array}{l}-0.052 \\
(0.039)\end{array}$ \\
\hline-0.294 & {$[-0.247]$} & {$[-0.215]$} & {$[-0.182]$} & {$[-0.151]$} & {$[-0.118]$} & {$[-0.089]$} & {$[-0.053]$} & {$[-0.018] \rho=-0.35$} \\
\hline $\begin{array}{l}\text { GCSE A*-C } \\
\text { Maths }\end{array}$ & $\begin{array}{c}-0.627 \\
(0.041)^{* * *}\end{array}$ & $\begin{array}{c}-0.541 \\
(0.041)^{* * *}\end{array}$ & $\begin{array}{c}-0.455 \\
(0.041)^{* * *}\end{array}$ & $\begin{array}{c}-0.370 \\
(0.041)^{* * *}\end{array}$ & $\begin{array}{c}-0.280 \\
(0.040)^{* * *}\end{array}$ & $\begin{array}{c}-0.201 \\
(0.040)^{* * *}\end{array}$ & $\begin{array}{c}-0.010 \\
(0.039)^{* *}\end{array}$ & $\begin{array}{c}0.105 \\
(0.038)^{* * *}\end{array}$ \\
\hline-0.282 & {$[-0.241]$} & {$[-0.208]$} & {$[-0.175]$} & {$[-0.142]$} & {$[-0.107]$} & {$[-0.076]$} & {$[-0.038]$} & {$[0.039] \rho=-0.41$} \\
\hline $\begin{array}{l}\text { A levels } \\
-0.233\end{array}$ & $\begin{array}{c}-0.516 \\
(0.044)^{* * *}\end{array}$ & $\begin{array}{c}-0.430 \\
(0.043)^{* * *}\end{array}$ & $\begin{array}{c}-0.342 \\
(0.043)^{* * *}\end{array}$ & $\begin{array}{c}-0.256 \\
(0.043)^{* * *}\end{array}$ & $\begin{array}{c}-0.165 \\
(0.043)^{* * *}\end{array}$ & $\begin{array}{c}-0.084 \\
(0.042)^{* *}\end{array}$ & $\begin{array}{c}0.016 \\
(0.042)\end{array}$ & $\begin{array}{c}0.230 \\
(0.0411)^{* * *}\end{array}$ \\
\hline & {$[-0.181]$} & [ -0.153] & {$[-0.123]$} & {$[-0.093]$} & {$[-0.061]$} & {$[-0.031]$} & {$[0.006]$} & {$[0.088] \rho=-0.41$} \\
\hline $\begin{array}{l}\text { A level in } \\
\text { Maths }\end{array}$ & $\begin{array}{c}-0.291 \\
(0.092)^{* * *}\end{array}$ & $\begin{array}{c}-0.199 \\
(0.092)^{* *}\end{array}$ & $\begin{array}{l}-0.105 \\
(0.092)\end{array}$ & $\begin{array}{l}-0.012 \\
(0.092)\end{array}$ & $\begin{array}{c}0.086 \\
(0.091)^{*}\end{array}$ & $\begin{array}{c}0.174 \\
(0.091)^{*}\end{array}$ & $\begin{array}{c}0.285 \\
(0.089)^{* * *}\end{array}$ & $\begin{array}{c}-0.123 \\
(0.092)\end{array}$ \\
\hline-0.044 & {$[-0.074]$} & {$[-0.052]$} & {$[-0.028]$} & {$[-0.003]$} & {$[0.025]$} & {$[0.051]$} & [0.087] & {$[-0.033] \rho=-0.09$} \\
\hline $\begin{array}{l}\text { A levels in } \\
\text { Science }\end{array}$ & $\begin{array}{c}-0.258 \\
(0.083)^{* * *}\end{array}$ & $\begin{array}{c}-0.166 \\
(0.083)^{* *}\end{array}$ & $\begin{array}{l}-0.073 \\
(0.083)\end{array}$ & $\begin{array}{c}0.019 \\
(0.082)\end{array}$ & $\begin{array}{c}0.116 \\
(0.082)^{*}\end{array}$ & $\begin{array}{c}0.203 \\
(0.081)^{* *}\end{array}$ & $\begin{array}{c}0.311 \\
(0.080)^{* *}\end{array}$ & $\begin{array}{c}-0.451 \\
(0.083)^{* * *}\end{array}$ \\
\hline-0.052 & {$[-0.082]$} & {$[-0.054]$} & {$[-0.024]$} & [0.006] & {$[0.040]$} & [0.072] & [0.112] & {$[-0.137] \rho=0.10$} \\
\hline $\begin{array}{l}\text { A levels in } \\
\text { English }\end{array}$ & $\begin{array}{l}-0.122 \\
(0.082)\end{array}$ & $\begin{array}{l}-0.029 \\
(0.082)\end{array}$ & $\begin{array}{c}0.063 \\
(0.082)\end{array}$ & $\begin{array}{c}0.155 \\
(0.082)^{*}\end{array}$ & $\begin{array}{c}0.251 \\
(0.081)^{* * *}\end{array}$ & $\begin{array}{c}0.337 \\
(0.081)^{* * *}\end{array}$ & $\begin{array}{c}0.444 \\
(0.080)^{* *}\end{array}$ & $\begin{array}{c}0.592 \\
(0.078)^{* * *}\end{array}$ \\
\hline-0.070 & {$[-0.039]$} & {$[-0.009]$} & [0.021] & [0.053] & [0.088] & {$[0.120]$} & [0.161] & {$[.218] \rho=-0.37$} \\
\hline
\end{tabular}

Note: Standard errors are in parentheses. Marginal effects in brackets * indicates that the underlying coefficient is significant at $10 \%$ level, ** at $5 \%$ and $* * * a t ~ 1 \%$. Additional variables included in the analysis are listed at p. 9. Results from an OLS regression of various outcomes on external locus of control with no additional covariates are reported in the first column in italic. 


\begin{tabular}{|c|c|c|c|c|}
\hline High work ethics & $\boldsymbol{\rho}=\mathbf{0}$ & $\rho=0.05$ & $\rho=0.1$ & $\begin{array}{l}\rho \text { set such that select on obs. }=\text { select } \\
\text { on unobs. }\end{array}$ \\
\hline $\begin{array}{l}\text { 5+GCSE A*-C } \\
0.079\end{array}$ & $\begin{array}{c}0.272 \\
(0.039)^{* * *} \\
{[0.106]}\end{array}$ & $\begin{array}{c}0.185 \\
(0.039)^{* * *} \\
{[0.072]}\end{array}$ & $\begin{array}{c}0.097 \\
(0.039)^{* *} \\
{[0.038]}\end{array}$ & $\begin{array}{c}0.239 \\
(0.039)^{* * *} \\
{[0.093] \rho=0.02}\end{array}$ \\
\hline $\begin{array}{l}\text { GCSE A*-C English } \\
0.069\end{array}$ & $\begin{array}{c}0.284 \\
(0.042)^{* * *} \\
{[0.094]}\end{array}$ & $\begin{array}{c}0.196 \\
(0.042)^{* * *} \\
{[0.066]}\end{array}$ & $\begin{array}{c}0.108 \\
(0.042)^{* *} \\
{[0.037]}\end{array}$ & $\begin{array}{c}0.231 \\
(0.042)^{* * *} \\
{[0.077] \rho=0.03}\end{array}$ \\
\hline $\begin{array}{l}\text { GCSE A*-C Maths } \\
0.070\end{array}$ & $\begin{array}{c}0.232 \\
(0.040)^{* * *} \\
{[0.085]}\end{array}$ & $\begin{array}{c}0.145 \\
(0.040)^{* * *} \\
{[0.054]}\end{array}$ & $\begin{array}{l}0.057 \\
(0.039) \\
{[0.021]}\end{array}$ & $\begin{array}{c}0.196 \\
(0.040)^{* * *} \\
{[0.072] \rho=0.02}\end{array}$ \\
\hline $\begin{array}{l}\text { A levels } \\
0.100\end{array}$ & $\begin{array}{c}0.253 \\
(0.038)^{* * *} \\
{[0.097]}\end{array}$ & $\begin{array}{c}0.165 \\
(0.038)^{* * *} \\
{[0.063]}\end{array}$ & $\begin{array}{c}0.078 \\
(0.038)^{* *} \\
{[0.029]}\end{array}$ & $\begin{array}{c}0.129 \\
(0.038)^{* * *} \\
{[0.049] \rho=0.07}\end{array}$ \\
\hline $\begin{array}{l}\text { A level in Maths } \\
0.009\end{array}$ & $\begin{array}{c}0.070 \\
(0.062) \\
{[0.019]}\end{array}$ & $\begin{array}{l}-0.014 \\
(0.062) \\
{[-0.004]}\end{array}$ & $\begin{array}{l}-0.098 \\
(0.061) \\
{[-0.027]}\end{array}$ & $\begin{array}{c}0.086 \\
(0.062) \\
{[0.024] \rho=-0.009}\end{array}$ \\
\hline $\begin{array}{l}\text { A levels in Science } \\
0.041\end{array}$ & $\begin{array}{c}0.206 \\
(0.057)^{* * *} \\
{[0.071]}\end{array}$ & $\begin{array}{c}0.121 \\
(0.057)^{* *} \\
{[0.041]}\end{array}$ & $\begin{array}{c}0.036 \\
(0.056) \\
{[0.012]}\end{array}$ & $\begin{array}{c}0.302 \\
(0.057)^{* *} \\
{[0.105] \rho=-0.05}\end{array}$ \\
\hline $\begin{array}{l}\text { A levels in English } \\
0.012\end{array}$ & $\begin{array}{c}-0.036 \\
(0.058) \\
{[-0.012]}\end{array}$ & $\begin{array}{l}-0.121 \\
(0.058) \\
{[-0.039]}\end{array}$ & $\begin{array}{l}-0.206 \\
(0.058) \\
{[-0.066]}\end{array}$ & $\begin{array}{c}0.059 \\
(0.058) \\
{[0.020] \rho=-0.05}\end{array}$ \\
\hline
\end{tabular}

Note: Standard errors are in parentheses. Marginal effects in brackets * indicates that the underlying coefficient is significant at $10 \%$ level, $* *$ at $5 \%$ and $* * *$ at $1 \%$. Additional variables included in the analysis are listed at p. 9. Results from an OLS regression of various outcomes on external locus of control with no additional covariates are reported in the first column in italic. 


\begin{tabular}{|c|c|c|c|c|}
\hline Low self-esteem & $\rho=0$ & $\rho=-0.05$ & $\rho=-0.1$ & $\begin{array}{l}\rho \text { set such that select on obs. }=\text { select } \\
\text { on unobs. }\end{array}$ \\
\hline 5+GCSE A*-C & $\begin{array}{c}-0.122 \\
(0.034)^{* * *}\end{array}$ & $\begin{array}{l}-0.037 \\
(.034)\end{array}$ & $\begin{array}{l}0.047 \\
(.034)\end{array}$ & $\begin{array}{c}-0.221 \\
(0.034)^{* * *}\end{array}$ \\
\hline-0.035 & {$[-0.048]$} & {$[-0.015]$} & [0.019] & {$[-0.088] \rho=0.06$} \\
\hline GCSE A*-C English & $\begin{array}{c}-0.065 \\
(0.035)^{*}\end{array}$ & $\begin{array}{r}0.019 \\
(0.035)\end{array}$ & $\begin{array}{c}0.103 \\
(0.035)^{* *}\end{array}$ & $\begin{array}{c}-0.226 \\
(0.035)^{* * *}\end{array}$ \\
\hline-0.008 & {$[-0.024]$} & [0.007] & {$[0.037]$} & {$[-0.083] \rho=0.09$} \\
\hline GCSE A*-C Maths & $\begin{array}{c}-0.170 \\
(0.034)^{* * *}\end{array}$ & $\begin{array}{c}-0.086 \\
(0.034)^{* *}\end{array}$ & $\begin{array}{l}-0.001 \\
(0.034)\end{array}$ & $\begin{array}{c}-0.217 \\
(0.034)^{* * *}\end{array}$ \\
\hline-0.058 & {$[-0.066]$} & {$[-0.033]$} & {$[-0.0005]$} & {$[-0.084] \rho=0.03$} \\
\hline A levels & $\begin{array}{l}-0.044 \\
(0.034)\end{array}$ & $\begin{array}{c}0.040 \\
(0.034)\end{array}$ & $\begin{array}{c}0.125 \\
(0.034)^{* * *}\end{array}$ & $\begin{array}{c}-0.161 \\
(0.034)^{* * *}\end{array}$ \\
\hline-0.006 & {$[-0.016]$} & {$[0.014]$} & {$[0.0467]$} & {$[-0.058] \rho=0.07$} \\
\hline A level in Maths & $\begin{array}{c}-0.206 \\
(0.062)^{* * *}\end{array}$ & $\begin{array}{c}-0.121 \\
(0.062)^{*}\end{array}$ & $\begin{array}{l}-0.035 \\
(0.061)\end{array}$ & $\begin{array}{c}0.011 \\
(0.061)\end{array}$ \\
\hline-0.054 & {$[-0.054]$} & {$[-0.032]$} & {$[-0.0095]$} & {$[0.003] \rho=-0.12$} \\
\hline A levels in Science & $\begin{array}{c}-0.167 \\
(0.056)^{* * *}\end{array}$ & $\begin{array}{l}-0.083 \\
(0.056)\end{array}$ & $\begin{array}{c}0.002 \\
(0.056)\end{array}$ & $\begin{array}{c}0.008 \\
(0.056)\end{array}$ \\
\hline-0.038 & {$[-0.054]$} & {$[-0.027]$} & {$[0.00087]$} & {$[0.002] \rho=-0.10$} \\
\hline $\begin{array}{l}\text { A levels in English } \\
0.053\end{array}$ & $\begin{array}{c}0.107 \\
(0.054)^{*} \\
{[0.036]}\end{array}$ & $\begin{array}{c}0.191 \\
(0.054)^{* * *} \\
{[0.065]}\end{array}$ & $\begin{array}{c}0.276 \\
(0.054)^{* * *} \\
{[0.095]}\end{array}$ & $\begin{array}{c}-0.595 \\
(0.051)^{* *} \\
{[-0.18] \rho=0.42}\end{array}$ \\
\hline
\end{tabular}

Note: Standard errors are in brackets. * indicates that the underlying coefficient is significant at $10 \%$ level, ** at $5 \%$ and ***at $1 \%$. Additional variables included in the analysis are listed at p. 9. Results from an OLS regression of various outcomes on external locus of control with no additional covariates are reported in the first column in italic. 
Figure 1 - Histogram of propensity scores of treatment vs. control group

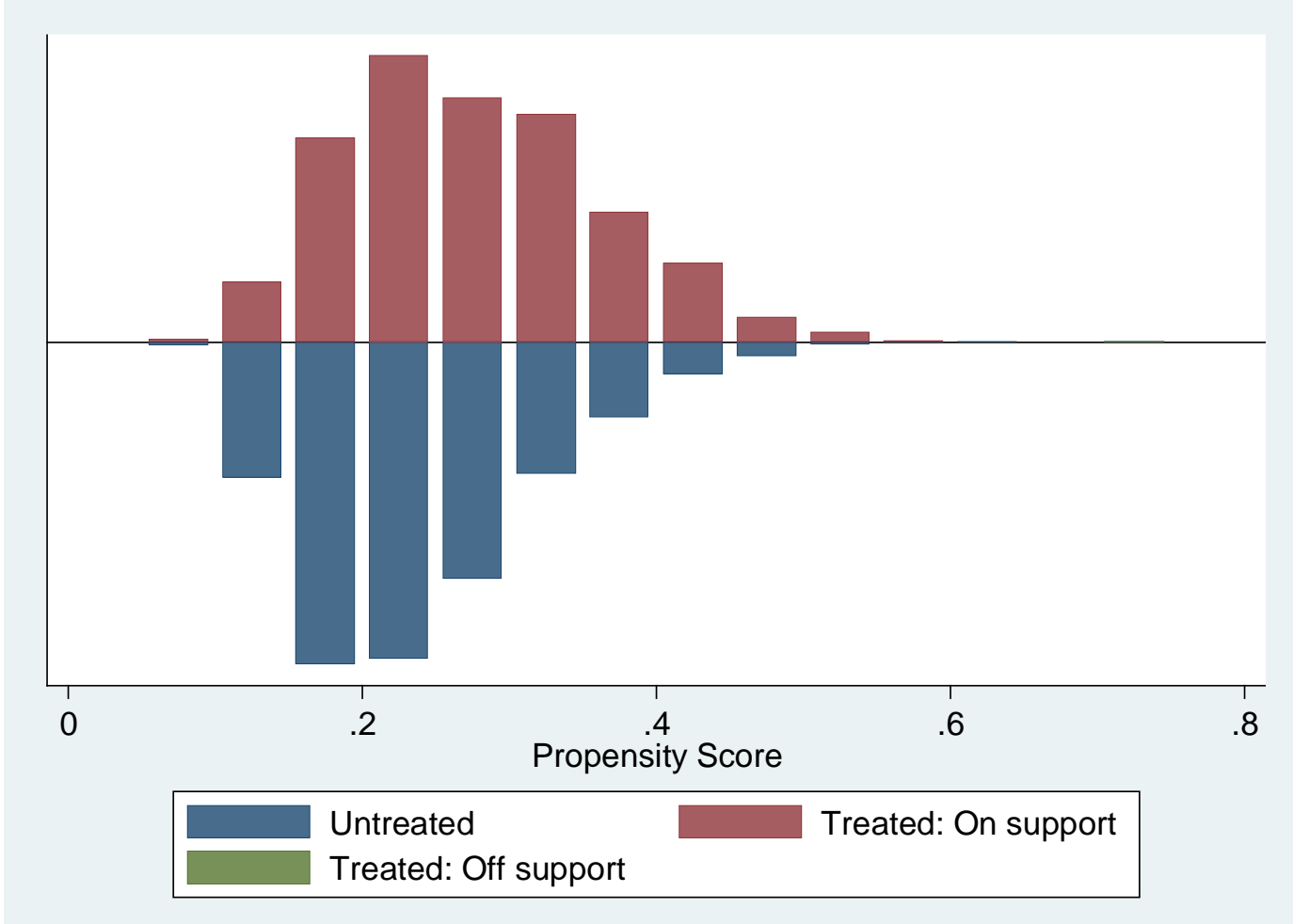

Figure 2 - Kernel graphs of propensity score for treated and control group

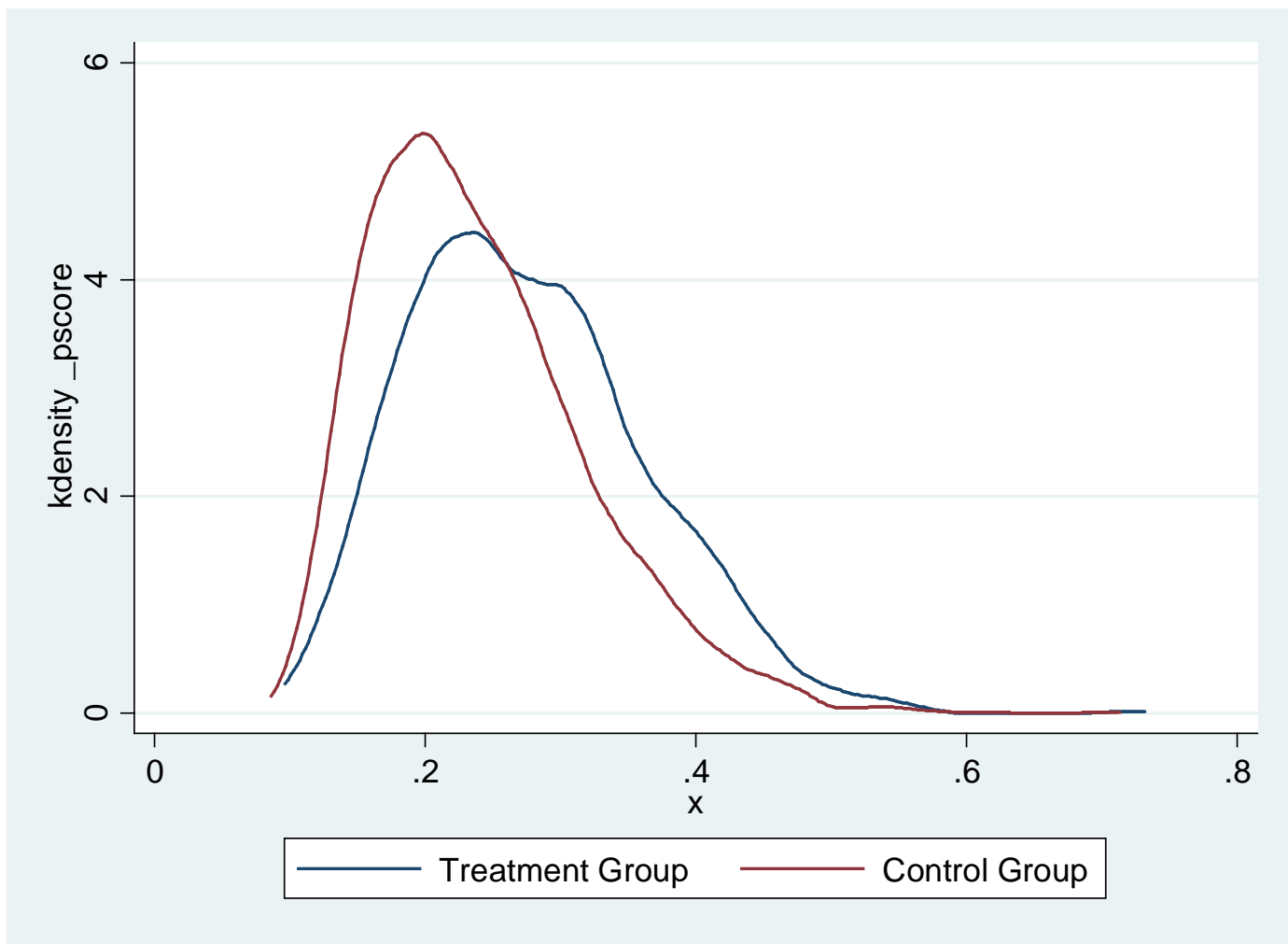

Model 2 - Effect of external locus of control on having 5 or more GCSE with A*-C. 


\section{Appendix}

\section{Locus of control - Questions in LSYPE}

1. I can pretty much decide what happens in my life

2. If someone is not a success in life, it is usually his fault

3. How well you get in this world is mostly a matter of luck

4. Even if I do well at school, I will have a hard time

5. People like me do not have much of a chance

6. If you work hard at something, you will usually succeed

Possible answers:

- Strongly agree

- Agree

- Disagree

- Strongly disagree

\section{Work ethics - Questions in LSYPE}

1. Doing well at school means a lot to me

2. At school, I work as hard as I can

3. Working hard at school now will help me to get on later in life

4. If you work hard at something, you will usually succeed

Possible answers:

- Strongly agree

- Agree

- Disagree

- Strongly disagree

\section{Self-esteem - Questions in LSYPE}

1. How useful you have felt recently?

2. How much you have been thinking of yourself as a worthless person recently?

Possible answers:

- Not at all

- No more than usual

- Rather more than usual

- Much more than usual. 
Table A1 Balance tests for Propensity Score Matching (Estimation of the effect of external locus of control on chances of getting 5+ GCSE A*-C - Model 2)

\begin{tabular}{|c|c|c|c|c|c|c|}
\hline Variable & $\begin{array}{l}\text { Mean - } \\
\text { Treated }\end{array}$ & Mean Control & $\%$ Bias & $\begin{array}{c}\% \text { Fall in } \\
\text { Bias }\end{array}$ & $\mathbf{t}$ & $\mathbf{p}$ \\
\hline $\begin{array}{l}\text { HH yearly income } \\
>31,200 £\end{array}$ & 0.247 & 0.268 & -4.5 & 82.9 & -1.27 & 0.203 \\
\hline $\begin{array}{l}\text { HH yearly income betw. } \\
11,400 £ \text { and } 31,200 £\end{array}$ & 0.487 & 0.464 & 4.6 & 66.1 & 1.23 & 0.220 \\
\hline Birth weight & 3.312 & 3.310 & 0.4 & 92.5 & 0.10 & 0.919 \\
\hline Premature birth & 0.098 & 0.093 & 1.8 & -22.2 & 0.50 & 0.614 \\
\hline Has older siblings & 1.025 & 1.003 & 2.0 & 88.2 & 0.50 & 0.620 \\
\hline $\begin{array}{l}\text { Grandparents went to } \\
\text { university }\end{array}$ & 0.069 & 0.061 & 3.0 & 64.1 & 0.90 & 0.368 \\
\hline Child has disabilty & 0.169 & 0.183 & -3.9 & 67.0 & -0.97 & 0.330 \\
\hline Main parent has disability & 0.219 & 0.222 & -0.8 & 85.0 & -0.22 & 0.823 \\
\hline $\begin{array}{l}\text { Mother has a } \\
\text { university degree }\end{array}$ & 0.091 & 0.092 & -0.2 & 98.8 & -0.06 & 0.949 \\
\hline $\begin{array}{l}\text { Mother has other } \\
\text { higher education }\end{array}$ & 0.119 & 0.135 & -4.6 & 52.1 & -1.28 & 0.200 \\
\hline $\begin{array}{l}\text { Mother senior high school } \\
\text { graduate }\end{array}$ & 0.153 & 0.153 & 0.0 & 100.0 & -0.00 & 1.000 \\
\hline $\begin{array}{l}\text { Mother junior high school } \\
\text { graduate }\end{array}$ & 0.282 & 0.280 & 0.5 & 93.1 & 0.12 & 0.901 \\
\hline $\begin{array}{l}\text { Mother has qualifications } \\
\text { level } 1 \text { or below }\end{array}$ & 0.112 & 0.127 & -4.9 & 51.6 & -1.20 & 0.230 \\
\hline $\begin{array}{l}\text { Mother has other } \\
\text { qualification }\end{array}$ & 0.038 & 0.033 & 2.7 & 56.6 & 0.70 & 0.487 \\
\hline Male & 0.543 & 0.545 & -0.3 & 95.5 & -0.07 & 0.941 \\
\hline Single parent at birth & 0.252 & 0.238 & 3.3 & 76.7 & 0.86 & 0.388 \\
\hline $\begin{array}{l}\text { Mother younger than } 20 \text { at } \\
\text { birth }\end{array}$ & 0.091 & 0.079 & 4.5 & 69.2 & 1.13 & 0.260 \\
\hline Black & 0.054 & 0.047 & 3.0 & -487.3 & 0.84 & 0.399 \\
\hline Asian & 0.088 & 0.075 & 4.4 & -302.2 & 1.22 & 0.223 \\
\hline Mixed & 0.077 & 0.096 & -7.3 & -3.7 & -1.78 & 0.076 \\
\hline $\begin{array}{l}\text { Mother was unemployed at } \\
\text { wave } 1\end{array}$ & 0.015 & 0.015 & -0.6 & 81.9 & -0.15 & 0.881 \\
\hline $\begin{array}{l}\text { Mother was out of the } \\
\text { labour force at wave } 1\end{array}$ & 0.288 & 0.274 & 3.2 & 80.7 & 0.83 & 0.409 \\
\hline Single mother at wave 1 & 0.274 & 0.266 & 2.1 & 88.1 & 0.54 & 0.587 \\
\hline
\end{tabular}

A summary of the distribution of the absolute bias shows that before matching: Mean $=$ $10.83 \mathrm{SD}=8.70$ and after matching: Mean $=2.81$; $\mathrm{SD}=1.96$

Table A1 shows results from balance tests of the estimation performed with Model 2 on the effect of external locus of control on the chances of getting 5 or more GCSE with grade A*-C. The output shows values of each variable for the matched sample. In each row, it shows the mean of the variable for the treatment group and the mean for the control group. It also shows the "\%bias," which is the standardized bias. This "bias" is defined as the difference of the mean values of the treatment group and the (not matched / matched) non treatment group, divided by the square root of the average sample variance in the treatment group and the not matched non treatment group. The 
table also shows the \% reduction in bias, which is how much of this bias was eliminated by matching. In this example, there are few variables exhibiting negative values for this column (meaning that the bias increased as a result of matching) and these are mostly cases in which the bias was already very low before matching. To assess balance, one should look at both the bias and the mean differences between treatment and control in the matched sample. In our example, the bias is significantly reduced after matching (the mean goes from 10.83 to 2.81). The last two columns present results from a t-test on the hypothesis that the mean value of each variable is the same in the treatment group and the non-treatment group after matching. If $\mathrm{p}>0.1$, the null hypothesis cannot be rejected on the $10 \%$ significance level. The null hypothesis that the mean values of the two groups do not differ after matching cannot be rejected for most of the variables included in our analysis. By matching, the differences between treatment group and non-treatment group are reduced considerably. 
Table A2 Effect of other independent variables on high school performance and subjects' choice - OLS Estimation Results from Model 2

\begin{tabular}{|c|c|c|c|c|c|}
\hline & 5+GCSE A*-C & $\begin{array}{c}\text { GCSE A*-C in } \\
\text { English } \\
\end{array}$ & $\begin{array}{c}\text { GCSE A*-C } \\
\text { in Maths }\end{array}$ & Has A level & A level points \\
\hline \multirow[t]{2}{*}{ HH income $>31,200 £$} & 0.119 & 0.129 & 0.104 & 0.111 & 15.706 \\
\hline & $(0.018)^{* * *}$ & $(0.017)^{* * *}$ & $(0.018)^{* * *}$ & $(0.019) * * *$ & $(8.530)^{*}$ \\
\hline Income betw. 11,400£ - & 0.014 & 0.022 & 0.015 & 0.012 & 3.589 \\
\hline $31,200 £$ & $(0.016)$ & $(0.015)$ & $(0.016)$ & $(0.016)$ & $(8.255)$ \\
\hline \multirow[t]{2}{*}{ Birth weight } & 0.032 & 0.026 & 0.043 & 0.003 & -3.922 \\
\hline & $(0.012)^{* * *}$ & $(0.011)^{* *}$ & $(0.012)^{* * *}$ & $(0.012)$ & $(5.536)$ \\
\hline \multirow[t]{2}{*}{ Premature birth } & -0.028 & -0.023 & -0.007 & -0.016 & -8.485 \\
\hline & $(0.022)$ & $(0.020)$ & $(0.022)$ & $(0.022)$ & (10.513) \\
\hline \multirow[t]{2}{*}{ Has older siblings } & -0.039 & -0.039 & -0.039 & -0.035 & -8.534 \\
\hline & $(0.006)^{* * *}$ & $(0.005) * * *$ & $(0.006)^{* * *}$ & $(0.006) * * *$ & $(3.041)^{* * *}$ \\
\hline \multirow{2}{*}{$\begin{array}{l}\text { Grandparents went to } \\
\text { university }\end{array}$} & 0.110 & 0.073 & 0.095 & 0.075 & 50.659 \\
\hline & $(0.021)^{* * *}$ & $(0.020)^{* * *}$ & $(0.021)^{* * *}$ & $(0.021)^{* * *}$ & $(8.437)^{* * *}$ \\
\hline \multirow[t]{2}{*}{ Child has disabilty } & -0.088 & -0.078 & -0.090 & -0.029 & 7.860 \\
\hline & $(0.017)^{* * *}$ & $(0.016)^{* * *}$ & $(0.017) * * *$ & $(0.017)^{*}$ & (8.583) \\
\hline \multirow{2}{*}{$\begin{array}{l}\text { Main parent has } \\
\text { disability }\end{array}$} & -0.034 & -0.046 & -0.016 & -0.030 & -1.970 \\
\hline & $(0.015)^{* *}$ & $(0.014) * * *$ & $(0.015)$ & $(0.015)^{* *}$ & $(7.465)$ \\
\hline \multirow{2}{*}{$\begin{array}{l}\text { Mother - } \\
\text { University degree }\end{array}$} & 0.333 & 0.299 & 0.303 & 0.318 & 89.468 \\
\hline & $(0.025)^{* * *}$ & $(0.023)^{* * *}$ & $(0.024)^{* * *}$ & $(0.025)^{* * *}$ & $(11.832)^{* * *}$ \\
\hline Mother - other & 0.225 & 0.257 & 0.211 & 0.216 & 50.680 \\
\hline Higher educ. & $(0.024)^{* * *}$ & $(0.022) * * *$ & $(0.023) * * *$ & $(0.024)^{* * *}$ & $(11.952)^{* * *}$ \\
\hline \multirow{2}{*}{$\begin{array}{l}\text { Mother senior high } \\
\text { school gr. }\end{array}$} & 0.194 & 0.216 & 0.199 & 0.148 & 37.695 \\
\hline & $(0.023)^{* * *}$ & $(0.022)^{* * *}$ & $(0.023) * * *$ & $(0.023) * * *$ & $(12.133)^{* * *}$ \\
\hline \multirow{2}{*}{$\begin{array}{l}\text { Mother junior high } \\
\text { school gr. }\end{array}$} & 0.120 & 0.146 & 0.130 & 0.067 & 15.518 \\
\hline & $(0.020) * * *$ & $(0.019)^{* * *}$ & $(0.020) * * *$ & $(0.020) * * *$ & (11.195) \\
\hline \multirow{2}{*}{$\begin{array}{l}\text { Mother has low } \\
\text { qualification }\end{array}$} & 0.015 & 0.024 & 0.036 & -0.034 & -9.850 \\
\hline & $(0.026)$ & $(0.024)$ & $(0.025)$ & $(0.026)$ & (15.581) \\
\hline \multirow{2}{*}{$\begin{array}{l}\text { Mother has other } \\
\text { qualification }\end{array}$} & 0.033 & 0.094 & 0.076 & 0.064 & 41.881 \\
\hline & $(0.038)$ & $(0.035) * * *$ & $(0.037)^{* *}$ & $(0.038)^{*}$ & $(20.703)^{* *}$ \\
\hline \multirow[t]{2}{*}{ Male } & -0.073 & -0.130 & -0.029 & -0.072 & -16.872 \\
\hline & $(0.012)^{* * *}$ & $(0.011)^{* * *}$ & $(0.012)^{* *}$ & $(0.012)^{* * *}$ & $(5.595) * * *$ \\
\hline \multirow[t]{2}{*}{ Single parent at birth } & -0.049 & -0.055 & -0.025 & -0.041 & -27.793 \\
\hline & $(0.017)^{* * *}$ & $(0.016)^{* * *}$ & $(0.017)$ & $(0.017)^{* *}$ & $(8.943)^{* * *}$ \\
\hline \multirow{2}{*}{$\begin{array}{l}\text { Mother younger than } 20 \\
\text { at birth }\end{array}$} & -0.186 & -0.194 & -0.194 & -0.154 & -73.538 \\
\hline & $(0.026)^{* * *}$ & $(0.024)^{* * *}$ & $(0.025)^{* * *}$ & $(0.026)^{* * *}$ & $(17.073)^{* * *}$ \\
\hline \multirow[t]{2}{*}{ Black } & -0.055 & 0.009 & -0.035 & -0.051 & -35.044 \\
\hline & $(0.027)^{* *}$ & $(0.025)$ & $(0.026)$ & $(0.027)^{*}$ & $(13.428)^{* * *}$ \\
\hline \multirow[t]{2}{*}{ Asian } & 0.136 & 0.120 & 0.141 & 0.188 & 8.481 \\
\hline & $(0.022)^{* * *}$ & $(0.021) * * *$ & $(0.022) * * *$ & $(0.023)^{* * *}$ & $(9.586)$ \\
\hline \multirow[t]{2}{*}{ Mixed } & 0.088 & 0.083 & 0.083 & 0.027 & 22.888 \\
\hline & $(0.025)^{* * *}$ & $(0.023) * * *$ & $(0.025) * * *$ & $(0.025)$ & $(11.735)^{*}$ \\
\hline \multirow{2}{*}{$\begin{array}{l}\text { Mother unemployed at } \\
\text { wave } 1\end{array}$} & -0.082 & 0.043 & -0.070 & -0.034 & -18.188 \\
\hline & $(0.055)$ & $(0.052)$ & $(0.055)$ & $(0.056)$ & (31.112) \\
\hline Mother out of the labour & -0.033 & -0.022 & -0.052 & -0.008 & 16.021 \\
\hline force at wave 1 & $(0.015)^{* *}$ & $(0.014)$ & $(0.015)^{* * *}$ & $(0.015)$ & $(7.577)^{* *}$ \\
\hline Single mother at & -0.067 & -0.034 & -0.082 & -0.070 & -11.575 \\
\hline wave 1 & $(0.017)^{* * *}$ & $(0.016)^{* *}$ & $(0.017)^{* * *}$ & $(0.017)^{* * *}$ & (9.043) \\
\hline Constant & 0.407 & 0.551 & 0.432 & 0.338 & 231.888 \\
\hline & $(0.046)^{* * *}$ & $(0.043)^{* * *}$ & $(0.045)^{* * *}$ & $(0.046)^{* * *}$ & $(22.789)^{* * *}$ \\
\hline$R^{2}$ & 0.22 & 0.23 & 0.20 & 0.17 & 0.13 \\
\hline$N$ & 5,572 & 5,572 & 5,572 & 5,646 & 2,278 \\
\hline
\end{tabular}

Note: Standard errors are in brackets. * indicates that the underlying coefficient is significant at $10 \%$ level, ** at $5 \%$ and $* * *$ at $1 \%$ 
Table A2 Effect of other independent variables on high school performance and subjects' choice - OLS Estimation Results from Model 2 - Cont.

\begin{tabular}{|c|c|c|c|c|c|c|c|}
\hline & $\begin{array}{l}\text { A levels in } \\
\text { Maths }\end{array}$ & $\begin{array}{l}\text { A levels in Maths - } \\
\text { Points }\end{array}$ & A level in Science & $\begin{array}{c}\text { A level in } \\
\text { Science -Points }\end{array}$ & A level in English & $\begin{array}{c}\text { A level } \\
\text { in English - Points }\end{array}$ & $\begin{array}{l}\text { N. of facilitating } \\
\text { subjects }\end{array}$ \\
\hline HH income & 0.055 & 5.941 & 0.048 & 6.450 & -0.011 & 0.673 & 0.179 \\
\hline$>31,200$ & $(0.026)^{* *}$ & $(3.333)^{*}$ & $(0.029)^{*}$ & $(4.704)$ & $(0.029)$ & $(2.871)$ & $(0.060)^{* * *}$ \\
\hline Income $11,400 £$ & 0.028 & 2.125 & 0.028 & 1.976 & -0.034 & -0.924 & 0.030 \\
\hline$-31,200 £$ & $(0.025)$ & (3.226) & $(0.028)$ & $(4.552)$ & $(0.028)$ & (2.779) & $(0.058)$ \\
\hline \multirow[t]{2}{*}{ Birth weight } & 0.005 & -0.725 & 0.014 & 1.347 & -0.018 & -1.712 & -0.002 \\
\hline & $(0.017)$ & (2.163) & $(0.019)^{\prime}$ & (3.053) & $(0.019)$ & $(1.864)$ & $(0.039)$ \\
\hline \multirow[t]{2}{*}{ Prem. birth } & -0.040 & -3.573 & -0.011 & -2.052 & -0.039 & -3.511 & -0.031 \\
\hline & $(0.032)$ & (4.108) & $(0.036)$ & (5.797) & $(0.036)$ & (3.539) & $(0.0580$ \\
\hline Has older & -0.032 & -3.419 & -0.024 & -4.230 & 0.002 & 0.039 & -0.075 \\
\hline siblings & $(0.009) * * *$ & $(1.188)^{* * *}$ & $(0.010)^{* *}$ & $(1.677)^{* *}$ & $(0.010)$ & $(1.024)$ & $(0.021)^{* * *}$ \\
\hline Grandp. went to & 0.053 & 5.195 & 0.072 & 15.484 & 0.029 & 4.382 & 0.156 \\
\hline university & $(0.026)^{* *}$ & (3.297) & $(0.029) * *$ & $(4.653)^{* * *}$ & $(0.029)$ & $(2.840)$ & $(0.060)^{* * *}$ \\
\hline Child has & -0.006 & 0.761 & -0.006 & 1.973 & 0.010 & 0.520 & -0.046 \\
\hline disabilty & $(0.026)$ & (3.354) & $(0.029)$ & (4.733) & $(0.029)$ & (2.889) & $(0.060)$ \\
\hline Main parent has & 0.008 & 2.701 & -0.015 & -1.783 & 0.007 & 0.603 & 0.020 \\
\hline disability & $(0.023)$ & $(2.917)$ & $(0.026)$ & (4.117) & $(0.025)$ & $(2.513)$ & $(0.052)$ \\
\hline Mother & 0.089 & 15.928 & 0.076 & 25.115 & 0.112 & 12.049 & 0.369 \\
\hline university degree & $(0.036)^{* *}$ & $(4.623)^{* * *}$ & $(0.041)^{*}$ & $(6.525)^{* * *}$ & $(0.040)^{* * *}$ & $(3.983)^{* * *}$ & $(0.084)^{* * *}$ \\
\hline Mother has other & 0.019 & 5.858 & 0.035 & 9.424 & 0.128 & 11.755 & 0.227 \\
\hline higher educ. & $(0.037)$ & $(4.670)$ & $(0.041)$ & (6.591) & $(0.041)^{* * *}$ & $(4.023)^{* * *}$ & $(0.084)^{* * *}$ \\
\hline Mother senior & 0.041 & 6.983 & 0.015 & 3.900 & 0.086 & 7.554 & 0.179 \\
\hline high school gr. & $(0.037)$ & $(4.741)$ & $(0.042)$ & (6.691) & $(0.041)^{* *}$ & $(4.084)^{*}$ & $(0.085)^{* *}$ \\
\hline Mother junior & 0.029 & 4.355 & -0.002 & 1.354 & 0.090 & 7.139 & 0.116 \\
\hline high school gr. & $(0.034)$ & $(4.375)$ & $(0.038)$ & $(6.174)$ & $(0.038)^{* *}$ & $(3.769)^{*}$ & $(0.079)$ \\
\hline Mother has low & -0.070 & -5.092 & -0.132 & -13.144 & 0.069 & 5.655 & -0.097 \\
\hline qualif. & $(0.048)$ & $(6.088)$ & $(0.053) * *$ & (8.592) & $(0.053)$ & $(5.245)$ & $(0.110)$ \\
\hline Mother has other & 0.079 & 6.224 & 0.076 & 14.474 & 0.039 & 3.399 & 0.205 \\
\hline qualification & $(0.064)$ & $(8.090)$ & $(0.071)$ & (11.417) & $(0.071)$ & (6.969) & $(0.146)$ \\
\hline \multirow[t]{2}{*}{ Male } & 0.128 & 14.531 & 0.076 & 6.616 & -0.177 & -16.369 & 0.015 \\
\hline & $(0.017)^{* * *}$ & $(2.186)^{* * *}$ & $(0.019)^{* * *}$ & $(3.085)^{* *}$ & $(0.019)^{* * *}$ & $(1.883)^{* * *}$ & $(0.040)$ \\
\hline Single parent at & -0.067 & -7.867 & -0.040 & -8.043 & 0.011 & -0.552 & -0.239 \\
\hline birth & $(0.028) * * *$ & $(3.494)^{* *}$ & $(0.031)$ & $(4.932)$ & $(0.030)$ & (3.010) & $(0.063)^{* * *}$ \\
\hline
\end{tabular}




\begin{tabular}{|c|c|c|c|c|c|c|c|}
\hline & $\begin{array}{l}\text { A levels in } \\
\text { Maths }\end{array}$ & $\begin{array}{c}\text { A levels in Maths - } \\
\text { Points }\end{array}$ & A level in Science & $\begin{array}{c}\text { A level in } \\
\text { Science-Points }\end{array}$ & A level in English & $\begin{array}{c}\text { A level } \\
\text { in English - Points }\end{array}$ & $\begin{array}{c}\text { N. of facilitating } \\
\text { subjects }\end{array}$ \\
\hline $\begin{array}{l}\text { Mother younger } \\
\text { than } 20 \text { at birth }\end{array}$ & $\begin{array}{l}-0.047 \\
(0.053)\end{array}$ & $\begin{array}{l}-8.777 \\
(6.671)\end{array}$ & $\begin{array}{l}-0.067 \\
(0.059)\end{array}$ & $\begin{array}{l}-8.378 \\
(9.415)\end{array}$ & $\begin{array}{l}-0.023 \\
(0.058)\end{array}$ & $\begin{array}{l}-1.944 \\
(5.747)\end{array}$ & $\begin{array}{l}-0.289 \\
(0.121)^{* *}\end{array}$ \\
\hline Black & $\begin{array}{l}-0.001 \\
(0.041)\end{array}$ & $\begin{array}{l}-3.246 \\
(5.247)\end{array}$ & $\begin{array}{l}-0.082 \\
(0.046)^{*}\end{array}$ & $\begin{array}{l}-15.650 \\
(7.405)^{* *}\end{array}$ & $\begin{array}{l}-0.012 \\
(0.046)\end{array}$ & $\begin{array}{l}-0.508 \\
(4.520)\end{array}$ & $\begin{array}{l}-0.228 \\
(0.095)^{* *}\end{array}$ \\
\hline Asian & $\begin{array}{l}0.193 \\
(0.029)^{* * *}\end{array}$ & $\begin{array}{l}20.877 \\
(3.746)^{* * *}\end{array}$ & $\begin{array}{l}0.124 \\
(0.033)^{* * *}\end{array}$ & $\begin{array}{l}20.905 \\
(5.286)^{* * *}\end{array}$ & $\begin{array}{l}-0.041 \\
(0.033)\end{array}$ & $\begin{array}{l}-4.466 \\
(3.227)\end{array}$ & $\begin{array}{c}0.034 \\
(0.068)\end{array}$ \\
\hline Mixed & $\begin{array}{l}0.136 \\
(0.036)^{* * *}\end{array}$ & $\begin{array}{l}17.084 \\
(4.585)^{* * *}\end{array}$ & $\begin{array}{l}0.118 \\
(0.040)^{* * *}\end{array}$ & $\begin{array}{l}19.777 \\
(6.471)^{* * *}\end{array}$ & $\begin{array}{l}-0.070 \\
(0.040)^{*}\end{array}$ & $\begin{array}{l}-6.151 \\
(3.950)\end{array}$ & $\begin{array}{l}0.172 \\
(0.083)^{* *}\end{array}$ \\
\hline $\begin{array}{l}\text { Mother was } \\
\text { unemployed at } \\
\text { wave } 1\end{array}$ & $\begin{array}{c}0.074 \\
(0.096)\end{array}$ & $\begin{array}{c}5.547 \\
(12.157)\end{array}$ & $\begin{array}{l}-0.061 \\
(0.107)\end{array}$ & $\begin{array}{l}-10.961 \\
(17.157)\end{array}$ & $\begin{array}{c}0.191 \\
(0.106)^{*}\end{array}$ & $\begin{array}{c}10.265 \\
(10.473)\end{array}$ & $\begin{array}{c}0.248 \\
(0.220)\end{array}$ \\
\hline $\begin{array}{l}\text { Mother was out } \\
\text { of the labour } \\
\text { force at wave } 1\end{array}$ & $\begin{array}{l}-0.008 \\
(0.023)\end{array}$ & $\begin{array}{c}0.143 \\
(2.960)\end{array}$ & $\begin{array}{c}0.036 \\
(0.026)\end{array}$ & $\begin{array}{c}6.342 \\
(4.178)\end{array}$ & $\begin{array}{c}0.023 \\
(0.026)\end{array}$ & $\begin{array}{c}2.203 \\
(2.550)\end{array}$ & $\begin{array}{c}0.051 \\
(0.054)\end{array}$ \\
\hline $\begin{array}{l}\text { Single mother } \\
\text { at wave } 1\end{array}$ & $\begin{array}{l}-0.026 \\
(0.028)\end{array}$ & $\begin{array}{l}-4.283 \\
(3.534)\end{array}$ & $\begin{array}{l}-0.025 \\
(0.031)\end{array}$ & $\begin{array}{l}-4.283 \\
(4.987)\end{array}$ & $\begin{array}{l}-0.023 \\
(0.031)\end{array}$ & $\begin{array}{l}-1.737 \\
(3.044)\end{array}$ & $\begin{array}{l}-0.070 \\
(0.064)\end{array}$ \\
\hline Constant & $\begin{array}{c}0.092 \\
(0.070)\end{array}$ & $\begin{array}{l}10.674 \\
(8.905)\end{array}$ & $\begin{array}{l}0.162 \\
(0.078)^{* *}\end{array}$ & $\begin{array}{c}19.039 \\
(12.567)\end{array}$ & $\begin{array}{l}0.359 \\
(0.078)^{* * *}\end{array}$ & $\begin{array}{l}31.868 \\
(7.671)^{* * *}\end{array}$ & $\begin{array}{c}0.992 \\
(0.161)^{* * *}\end{array}$ \\
\hline$R^{2}$ & 0.08 & 0.08 & 0.06 & 0.07 & 0.06 & 0.05 & 0.08 \\
\hline$N$ & 2,278 & 2,278 & 2,278 & 2,278 & 2,278 & 2,278 & 2,278 \\
\hline
\end{tabular}

Note: Standard errors are in brackets. * indicates that the underlying coefficient is significant at $10 \%$ level, $* *$ at $5 \%$ and $* * * a t 1 \%$. 